\title{
Impact of Multiple Hydrogen Bonds with Fluoride on Catalysis: Insight from NMR Spectroscopy
}

\author{
Francesco Ibba, Gabriele Pupo, Amber L. Thompson, John M. Brown, Timothy D. W. Claridge,* \\ and Véronique Gouverneur*
}

Cite This: J. Am. Chem. Soc. 2020, 142, 19731-19744

Read Online

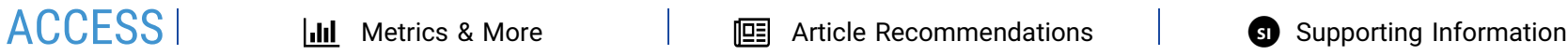

ABSTRACT: Hydrogen-bonding interactions have been explored in catalysis, enabling complex chemical reactions. Recently, enantioselective nucleophilic fluorination with metal alkali fluoride has been accomplished with BINAM-derived bisurea catalysts, presenting up to four $\mathrm{NH}$ hydrogen-bond donors (HBDs) for fluoride. These catalysts bring insoluble CsF and KF into solution, control fluoride nucleophilicity, and provide a chiral microenvironment for enantioselective fluoride delivery to the electrophile. These attributes encouraged a ${ }^{1} \mathrm{H} /{ }^{19} \mathrm{~F}$ NMR study to gain information on hydrogen-bonding networks with fluoride in solution, as well as how these arrangements impact the efficiency of catalytic nucleophilic fluorination. Herein, NMR experiments enabled the determination

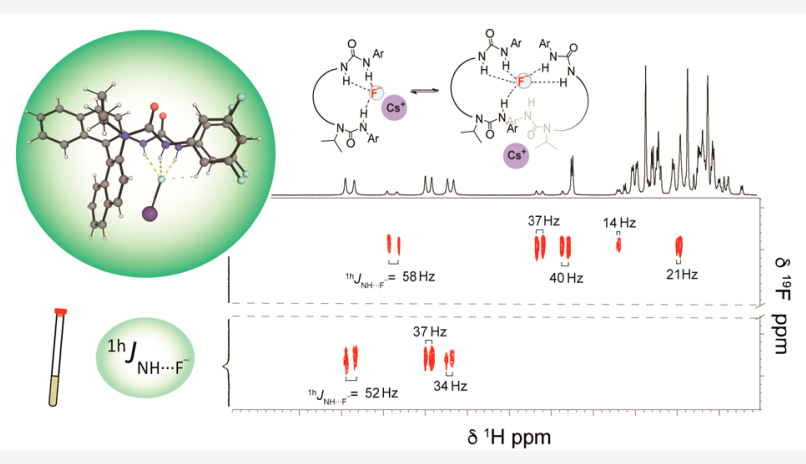
of the number and magnitude of $\mathrm{HB}$ contacts to fluoride for thirteen bisurea catalysts. These data supplemented by diagnostic coupling constants ${ }^{1 \mathrm{~h}} \mathrm{~J}_{\mathrm{NH} \cdots \mathrm{F}^{-}}$give insight into how multiple $\mathrm{H}$ bonds to fluoride influence reaction performance. In dichloromethane (DCM- $\left.d_{2}\right)$, nonalkylated BINAM-derived bisurea catalyst engages two of its four $\mathrm{NH}$ groups in hydrogen bonding with fluoride, an arrangement that allows effective phase-transfer capability but low control over enantioselectivity for fluoride delivery. The more efficient $\mathrm{N}$-alkylated BINAM-derived bisurea catalysts undergo urea isomerization upon fluoride binding and form dynamically rigid trifurcated hydrogen-bonded fluoride complexes that are structurally similar to their conformation in the solid state. Insight into how the countercation influences fluoride complexation is provided based on NMR data characterizing the species formed in DCM- $d_{2}$ when reacting a bisurea catalyst with tetra- $n$-butylammonium fluoride (TBAF) or CsF. Structure-activity analysis reveals that the three hydrogen-bond contacts with fluoride are not equal in terms of their contribution to catalyst efficacy, suggesting that tuning individual electronic environment is a viable approach to control phasetransfer ability and enantioselectivity.

\section{INTRODUCTION}

Hydrogen bonding (HB) is an important force for molecular recognition and for shaping the three-dimensional structure of molecules as large as proteins. In the past decade, hydrogenbond donors (HBD) have also found widespread applications in asymmetric catalysis offering an alternative to Brønsted and Lewis acid catalysts. ${ }^{1}$ For example, dual HBD catalysts promote enantioselective nucleophilic additions through direct binding to neutral electrophiles ${ }^{2}$ or via the formation of chiral ion pair intermediates. ${ }^{3}$ In the latter scenario commonly referred to as anion-binding catalysis, an electrophile is ionized by a chiral HBD catalyst generating an ion pair, with the resulting anionic hydrogen-bonded species creating a chiral environment for the cation to react with an external nucleophile. These approaches that build on pioneering studies in non-asymmetric cases ${ }^{4}$ have enabled a wide range of transformations involving heteroatom-stabilized cations including acyl-Pictet-Spengler reactions, ${ }^{5 a}$ acyl-Mannich reaction, ${ }^{5 \mathrm{~b}}$ and additions to oxocarbenium ions. ${ }^{5 \mathrm{c}}$ In further developments, HBD and Lewis acid catalysts were combined for enantioselective reactions involving less-reactive electrophiles. ${ }^{6}$ Specifically, chiral squaramides were used to activate silyl triflates via triflate abstraction, forming a highly Lewis acidic complex capable of generating oxocarbenium ion intermediates from acetals for enantioselective nucleophilic additions. ${ }^{6 a}$ Such a dual-catalyst system also enables activation of propargyl acetates into tertiary carbocationic intermediates that lack heteroatom stabilization for enantioconvergent catalytic $\mathrm{S}_{\mathrm{N}} 1$ reactions. ${ }^{6 \mathrm{~b}}$ An underdeveloped manifold in chiral ion pair organocatalysis consists of using the hydrogenbonded anion itself as the nucleophile. Hydrogen bonding is

Received: September 14, 2020

Published: November 9, 2020 
expected to decrease nucleophilicity, a challenge that led to creative solutions. ${ }^{7}$ For example, the combination of a chiral squaramide and pro-nucleophile bromotrimethylsilane (TMSBr) allowed for highly enantioselective ring-opening of oxetanes with in situ released bromide bound to the chiral HBD catalyst. $^{7 \mathrm{a}}$ Our laboratory disclosed an alternative approach for nucleophile activation whereby hydrogen bonding is merged with phase-transfer catalysis (Figure 1A). Specifically, an insoluble and unreactive inorganic salt selected as a nucleophile is solubilized by the chiral HBD that serves as a solid-liquid phase-transfer catalyst. The resulting, now soluble hydrogen-bonded anion can act as a competent nucleophile and undergo enantiocontrolled reaction with a cationic electrophilic partner (Figure 1B). This approach,

A

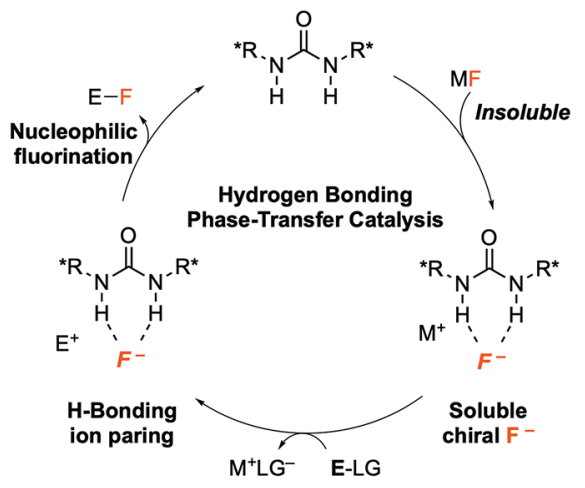

B
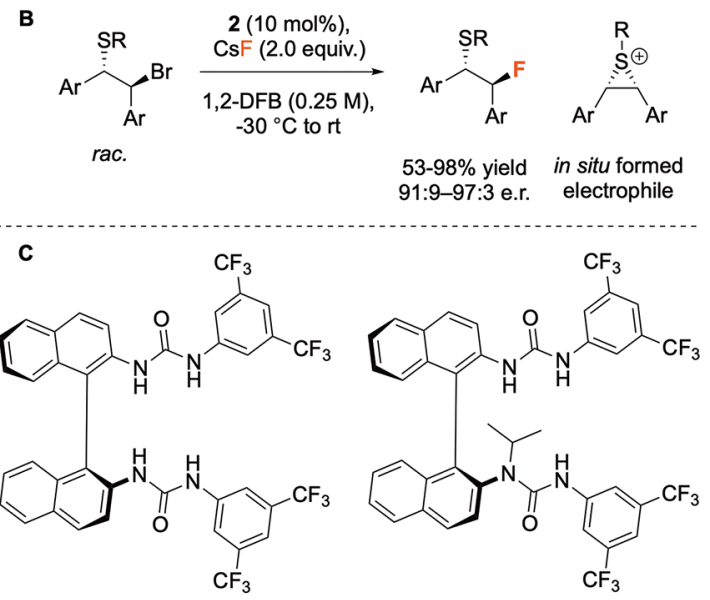

1 (S)-BINAM urea

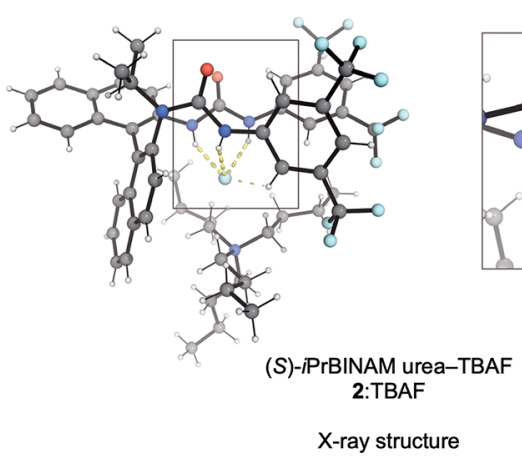

Figure 1. (A) Proposed mechanism for hydrogen-bonding phasetransfer catalysis (HB-PTC). (B) Asymmetric fluorination of $\beta$ bromosulfides under HB-PTC. (C) BINAM-derived bisurea catalysts $\mathbf{1}$ and $\mathbf{2}$ and solid-state structure of 2:TBAF from single-crystal X-ray diffraction. coined hydrogen-bonding phase-transfer catalysis (HB-PTC), was applied to asymmetric $\mathrm{C}-\mathrm{F}$ bond formation with $\mathrm{CsF}$ or $\mathrm{KF}$ in organic solvents.

For HB-PTC, the chiral BINAM-derived bisurea catalysts 1 and 2 shown in Figure $1 \mathrm{C}$ were engineered to coordinate fluoride in a manner reminiscent of the naturally occurring fluorinase enzyme. ${ }^{9}$ Highly enantioselective nucleophilic substitution of $\beta$-bromosulfides or $\beta$-chloramines was achieved via ring-opening of in situ formed meso-episulfonium or -aziridinium ions with metal alkali fluorides. ${ }^{8 \mathrm{a}, \mathrm{b}}$ Enantioenriched $\gamma$-fluoroamines were also within reach from achiral azetidinium salts applying HB-PTC. ${ }^{8 \mathrm{c}}$ For selected transformations, $2.5 \mathrm{~mol} \%$ of the phase-transfer catalyst was sufficient to reach high yield and enantioselectivity. NAlkylation of the bisurea catalyst improved performance, suggesting that this structural modification influences conformational preference and the ability of the catalyst to engage in hydrogen bonding with fluoride.

While fluoride binding to HBD is an active area of research in supramolecular chemistry, ${ }^{10}$ applications to asymmetric catalytic fluorination have been overlooked for many years, and data on how the number, strength, and directionality of hydrogen bonds with fluoride influence its nucleophilicity have only recently appeared. ${ }^{11}$ Valuable information on the spatial arrangement of the chiral tetrabutylammonium (TBA) $\mathrm{N}$ isopropyl bisurea-fluoride complex 2:TBAF was obtained from a single-crystal X-ray diffraction measurement that revealed three distinct $\mathrm{N}-\mathrm{H} \cdots \mathrm{F}^{-}$hydrogen-bonding interactions (Figure 1C).

A ${ }^{1} \mathrm{H} /{ }^{19} \mathrm{~F}$ NMR study is ideally suited to define the precise nature of $\mathrm{H}$-bonding to fluoride under conditions that simulate catalytic fluorination. Herein, we report the results of a detailed investigation performed on a selection of thirteen chiral bisurea catalysts enabling fluorinations under HB-PTC. The analyses of 1D NMR spectra and quantitative nuclear Overhauser effect (NOE) studies were used to study conformational changes of the catalysts upon binding to fluoride. Scalar couplings across hydrogen bonding, ${ }^{1 \mathrm{~h}} \mathrm{~J}_{\mathrm{NH} \cdots \mathrm{F}^{-}},{ }^{12}$ provide valuable information on the number and magnitude of catalyst-fluoride interactions. The characterization of the first bisurea-CsF complex in the solid state and in solution provides important insight on counterion effects, as well as on the species leading to successful catalytic fluorination with CsF under HB-PTC. This study unveils the existence of a range of multifurcated hydrogen-bonded fluoride complexes in solution and enables an analysis that correlates structural features with performance.

\section{RESULTS AND DISCUSSION}

Conformational Properties of BINAM-Derived Bisurea Catalysts. Polar aromatic solvents such as 1,2-difluorobenzene are optimal for fluorination under HB-PTC; chlorinated solvents such as chloroform and dichloromethane are also effective. In this study, spectra were recorded in DCM$d_{2}$ because of its noncoordinating nature, optimal chemical shift dispersion, and favorable temperature range. When possible, the concentration was set to $25 \mathrm{mM}$ to reflect the reaction conditions applied for enantioselective fluorination under HB-PTC.

Initially, BINAM bisurea $\mathbf{1}$ and its $\mathrm{N}$-isopropylated analogue 2 served to investigate the effect of $\mathrm{N}$-alkylation on conformational change to the catalyst. A combination of total correlation spectroscopy (TOCSY), heteronuclear single quantum coherence spectroscopy (HSQC), and heteronuclear 
multiple bond correlation spectroscopy (HMBC) $\left({ }^{1} \mathrm{H}-{ }^{13} \mathrm{C}\right.$ and ${ }^{1} \mathrm{H}-{ }^{15} \mathrm{~N}$ ) allowed for unambiguous assignment of all proton and carbon resonances of $\mathbf{1}$ and $2 .{ }^{13}$ Nonalkylated bisurea 1 shows uniformly sharp peaks in ${ }^{1} \mathrm{H}$ and ${ }^{13} \mathrm{C}$ NMR spectra (Figure 2, top). The chemical shifts are consistent with
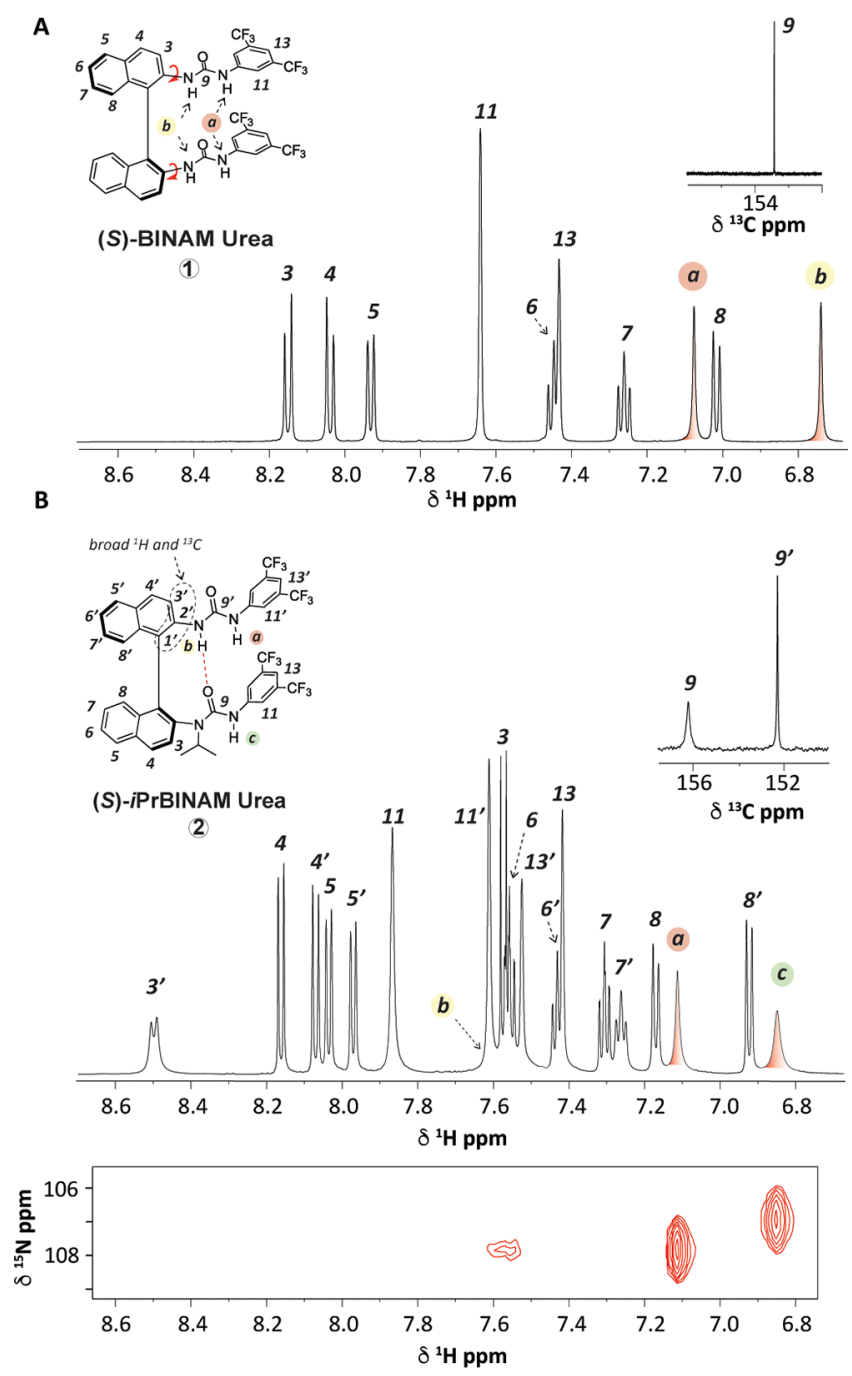

Figure 2. (A) Detail of ${ }^{1} \mathrm{H}$ and ${ }^{13} \mathrm{C}$ NMR of 1. (B) Detail of ${ }^{1} \mathrm{H},{ }^{13} \mathrm{C}$ $\mathrm{NMR}$, and ${ }^{1} \mathrm{H}-{ }^{15} \mathrm{~N}$ HSQC of 2 (DCM- $\left.d_{2}, 25 \mathrm{mM}, 298 \mathrm{~K}\right)$.

electronic environments, with $\mathrm{NH}(\mathrm{a})$ proximal to electrondeficient 3,5-bis(trifluoromethyl)phenyl groups deshielded with respect to $\mathrm{NH}(\mathrm{b})$, which are positioned close to the BINAM scaffold. In contrast to $\mathbf{1}$, line broadening was observed for selected peaks in the ${ }^{1} \mathrm{H}$ and ${ }^{13} \mathrm{C}$ NMR spectra of $\mathrm{N}$-isopropyl bisurea 2 (Figure 2, bottom). The resonances assigned to $\mathrm{NH}(\mathrm{a})$ and $\mathrm{NH}(\mathrm{c})$ appear at 7.1 and $6.9 \mathrm{ppm}$, respectively; $\mathrm{NH}(\mathrm{b})$ overlaps with multiple peaks in a range of common deuterated solvents (DCM- $d_{2}, \mathrm{CDCl}_{3}$, tetrahydrofuran (THF- $\left.d_{8}\right), \mathrm{CD}_{3} \mathrm{CN}$, dimethyl sulfoxide (DMSO- $d_{6}$ ), and $\mathrm{MeOD})$ and, at first glance, was difficult to locate due to broadening $(>70 \mathrm{~Hz})$. In DCM- $d_{2}$, the chemical shift of $\mathrm{NH}(\mathrm{b})$ was estimated at $\sim 7.6 \mathrm{ppm}$ based on cross-peaks in ${ }^{1} \mathrm{H}$ nuclear Overhauser effect spectroscopy (NOESY) and ${ }^{1} \mathrm{H}-{ }^{15} \mathrm{~N}$ $\mathrm{HSQC}^{13}$ this was unexpected as $\mathrm{NH}(\mathrm{b})$ is in a less electrondeficient environment than $\mathrm{NH}(\mathrm{a})$ and $\mathrm{NH}(\mathrm{c})$. In DMSO$d_{6},{ }^{14} \mathrm{NH}(\mathrm{a})$ and $\mathrm{NH}(\mathrm{c})$ are deshielded $(+1.5$ and $+0.8 \mathrm{ppm}$, respectively) likely due to hydrogen bonding with the solvent, while $\mathrm{NH}(\mathrm{b})$ is minimally affected $(+0.2 \mathrm{ppm})$. This observation alludes to $\mathrm{NH}(\mathrm{b})$ engaging in intramolecular hydrogen bonding with $\mathrm{O}=\mathrm{C}(9)$ (broad ${ }^{13} \mathrm{C}$ signal deshielded at $156.2 \mathrm{ppm}$; Figure 2, inset).

Peak line width $\left(\nu_{1 / 2}=\right.$ half-height line width $)$ is an important NMR observable correlating with the transverse relaxation rate $R_{2}\left(R_{2}=1 / T_{2} \approx \nu_{1 / 2}, \mathrm{~Hz}\right)$ and thereby with dynamic behavior of molecules in solution. ${ }^{15}$ Specifically, signal broadening observed for $\mathrm{H}\left(3^{\prime}\right), \mathrm{C}\left(3^{\prime}\right), \mathrm{C}\left(2^{\prime}\right), \mathrm{C}\left(1^{\prime}\right)$, and $\mathrm{C}(9)$ is consistent with a dynamic conformational exchange on the NMR time scale involving the hydrogenbond interaction $\mathrm{NH}(\mathrm{b}) \cdots \mathrm{O}=\mathrm{C}(9)$. The ${ }^{1} \mathrm{H}$ NMR spectra of both 1 and 2 were also recorded at varying concentrations. Significant changes were observed for 1 between 2 and $64 \mathrm{mM}$, with all protons bound to carbons experiencing shielding $\left(\Delta \delta_{\mathrm{H}(11)}=-211 \mathrm{ppb}\right)$, while deshielding was observed for the $\mathrm{NH}\left(\Delta \delta_{\mathrm{NH}(\mathrm{a})}=+300 \mathrm{ppb}, \Delta \delta_{\mathrm{NH}(\mathrm{b})}=+227 \mathrm{ppb}\right)$. This pattern suggests intermolecular aggregation. In contrast to $\mathbf{1}$, the ${ }^{1} \mathrm{H}$ NMR spectra of 2 display minimal variations in chemical shifts at higher concentration, a result suggesting reluctance to form intermolecular aggregates.

Insight into the conformational preference of 2 in DCM- $d_{2}$ was deduced from analysis of through-space correlations by means of high-resolution ${ }^{1} \mathrm{H}$ NOESY (Figure 3). Strong

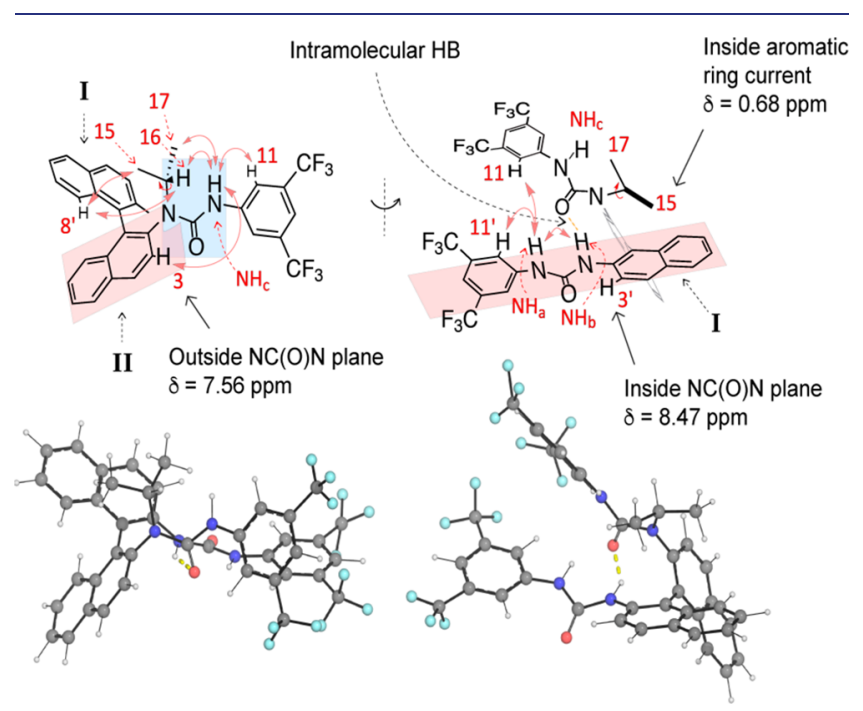

Figure 3. Conformation of 2 based on ${ }^{1} \mathrm{H}$ NOESY correlations (DCM- $\left.d_{2}, 25 \mathrm{mM}, 298 \mathrm{~K}\right)$.

correlations between the isopropyl protons $\mathrm{H}(15), \mathrm{H}(16)$, $\mathrm{H}(17)$, and $\mathrm{NH}(\mathrm{c})$ are consistent with the $\mathrm{N}$-iPr urea adopting an anti-anti conformation. ${ }^{13}$ Nuclear Overhauser effect (NOE) between isopropyl and $\mathrm{H}\left(8^{\prime}\right)$ indicates that the $N$ alkyl group is within close distance to naphthyl(I), while the $\mathrm{NH}(\mathrm{a}) \Leftrightarrow \mathrm{H}(11)$ interaction suggests that the two ureas are proximal to each other. The different orientations of the two ureas with respect to the BINAM scaffold explains the pronounced variations in chemical shifts between $\mathrm{H}\left(3^{\prime}\right)$ and $\mathrm{H}$ (3) (8.47 vs. $7.56 \mathrm{ppm}$ ), with both positioned on the naphthyl group ortho to the urea substituent. The carbonyl group affects the chemical shifts of neighboring protons by means of anisotropic electron circulation; as a result $\mathrm{H}\left(3^{\prime}\right)$, which is coplanar with the urea, is deshielded, whereas this is not the case for $\mathrm{H}(3)$ being out of plane. Together, these observations suggest that the two ureas are approximately perpendicular to each other. Magnetic anisotropy effects 
account for the shielding of the two diastereotopic methyls belonging to isopropyl. Protons 17 appear at $1.03 \mathrm{ppm}$ as a sharp doublet, while $\mathrm{H}(15)$ pointing toward naphthyl(I) appears as a broad singlet at $0.68 \mathrm{ppm}$. Data in the solid state could not be secured because recrystallization of 2 afforded fine needles that were unsuitable for single-crystal X-ray diffraction studies.

A range of $\mathrm{N}$-alkylated BINAM bisureas with various $\mathrm{N}$ substituents and electronic patterns for the aryl rings were synthesized and analyzed by NMR spectroscopy in DCM- $d_{2}$ (Figure 4A). The spectra of N-alkylated analogues 3-7 all
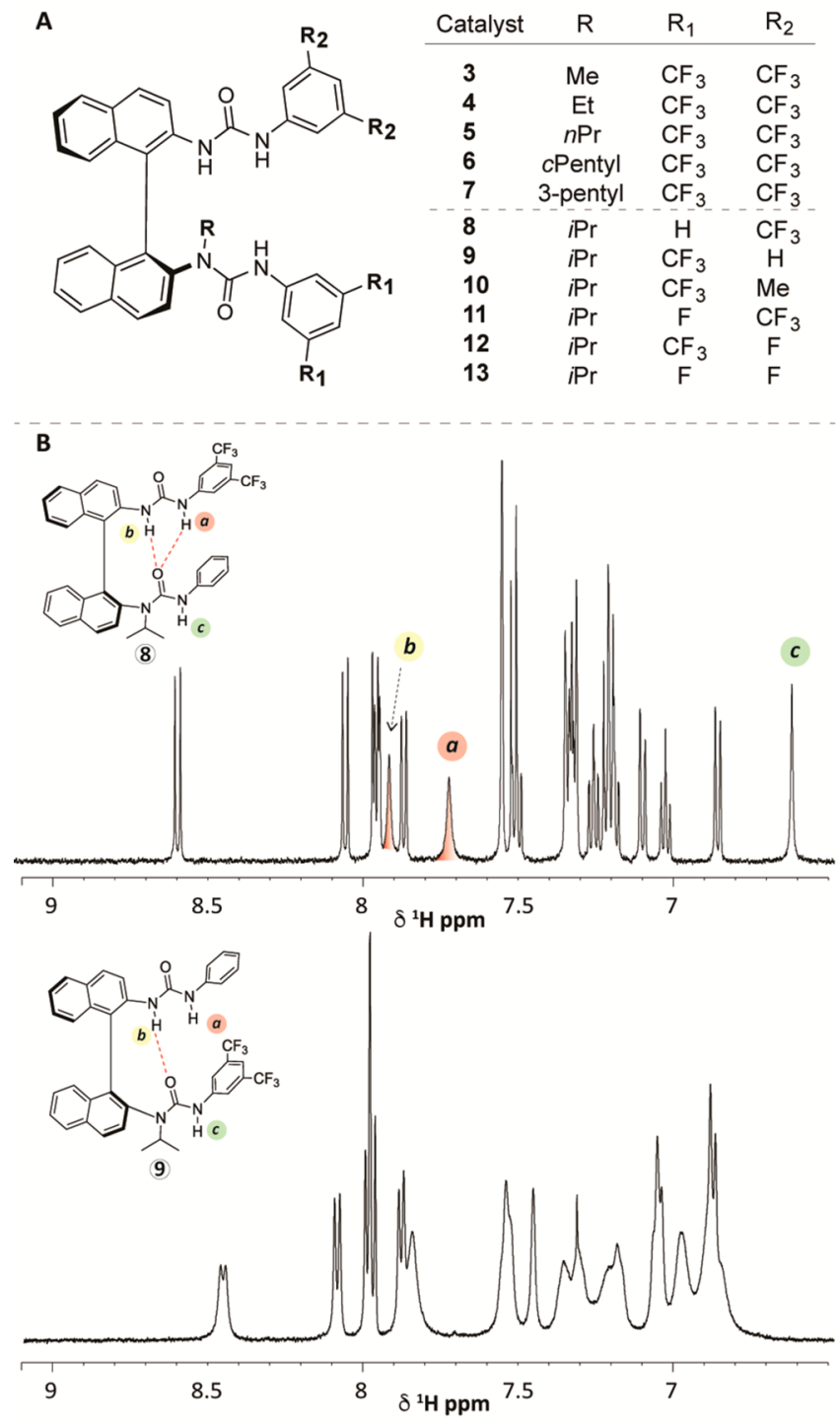

Figure 4. (A) Structures of the BINAM-derived bisurea catalysts 313. (B) ${ }^{1} \mathrm{H}$ NMR of 8 (top) and 9 (bottom) (DCM- $d_{2}, 25 \mathrm{mM}, 298$ $\mathrm{K})$.

featuring two 3,5-bis(trifluoromethyl)phenyl substituents were very similar to $N$-isopropyl bisurea 2 , implying analogous conformational preference. For this series, all $\mathrm{NH}(\mathrm{b})$ are more deshielded than $\mathrm{NH}(\mathrm{a}) / \mathrm{NH}(\mathrm{c})$ and appear broader; the $\mathrm{C}(9)$ and $\mathrm{H}\left(3^{\prime}\right)$ signals are also broader and deshielded compared to $\mathrm{C}\left(9^{\prime}\right)$ and $\mathrm{H}(3)$, respectively. When the aryl group linked to the $\mathrm{N}$-alkylated urea is the less electron-deficient phenyl group $\left(\mathrm{R}_{1}=\mathrm{Ph}\right.$, catalyst 8$)$, an additional hydrogen-bond interaction
$\mathrm{NH}(\mathrm{a}) \cdots \mathrm{O}=\mathrm{C}$ is observed that is consistent with increased Lewis basicity of the carbonyl oxygen (Figure 4B, top). This interaction confers conformational rigidity, giving rise to sharp proton and carbon resonances. In contrast, when the aromatic ring of the nonalkylated urea is phenyl $\left(R_{2}=P h\right.$, catalyst 9), the ${ }^{1} \mathrm{H}$ and ${ }^{13} \mathrm{C}$ NMR spectra are broader, suggesting the existence of a more dynamic structure likely resulting from weaker intramolecular hydrogen-bonding interactions (Figure 4B, bottom).

Complexation of Bisureas with TBAF. Formation of a hydrogen-bonded bisurea-fluoride complex is the cornerstone for successful enantioselective fluorinations with metal alkali fluoride under HB-PTC. Structural insight of these complexes in solution is therefore crucial for further development. The binding affinities of bisurea $\mathbf{1}$ and $\mathrm{N}$-isopropyl bisurea $\mathbf{2}$ for fluoride were investigated by spectrophotometry (Figure 5).

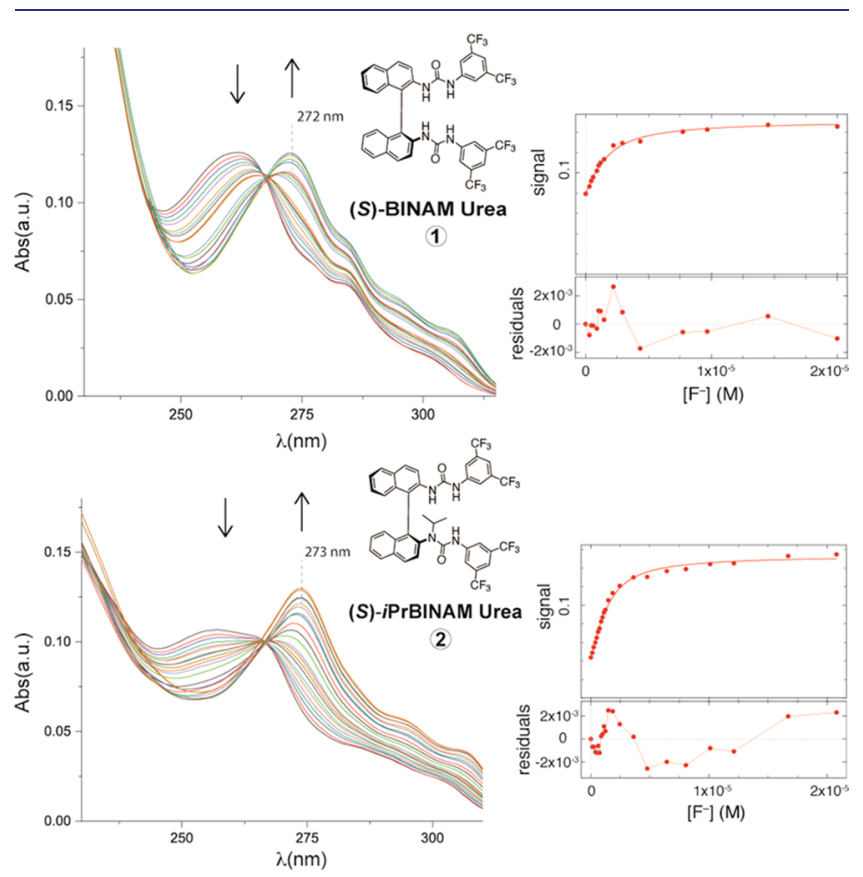

Figure 5. Stacked UV spectra recorded for the titration of $\mathbf{1}(1.2 \mu \mathrm{M})$ and $2(1.4 \mu \mathrm{M})$ with TBAF. $3 \mathrm{H}_{2} \mathrm{O}(0.1 \mathrm{mM})$ in DCM at $298 \mathrm{~K}$. On the right, titration profiles at the $\lambda_{\max }$ (red dots) and fitting functions (red lines). ${ }^{13}$

UV titrations carried out with 1 or 2 (1.2 and $1.4 \mu \mathrm{M}$, respectively) were performed in DCM by adding a solution of tetra- $n$-butylammonium fluoride of exact concentration quantified by ${ }^{19} \mathrm{~F}$ NMR (TBAF. $3 \mathrm{H}_{2} \mathrm{O}$ in DCM, $0.1 \mathrm{mM}$ ). ${ }^{13}$ Upon addition of an increasing amount of TBAF (0-15 equiv), UV spectra showed a bathochromic shift with the buildup of a new maximum of absorption $\left(\lambda_{\max }\right)$ at 273-275 $\mathrm{nm}$. The binding constants and energies were calculated from the titration profiles at $\lambda_{\max }$ via nonlinear least-squares regression using dedicated software. ${ }^{16}$ Both $1: 1$ and 2:1 binding modes were considered, with 1:1 giving superior fitting results. A 1:1 binding mode was also consistent with the clean isosbestic points observed. Association constants in the range of $10^{6} \mathrm{M}^{-1}$ denote strong and similar binding affinities of $\mathbf{1}$ and 2 to fluoride (Table 1 ).

Next, ${ }^{1} \mathrm{H}$ NMR titrations were performed at $3 \mathrm{mM}$ concentration in DCM- $d_{2}$. Addition of a TBAF solution (TBAF-3 $\mathrm{H}_{2} \mathrm{O}$ in DCM- $d_{2}, 55 \mathrm{mM}$ ) to 1 led to line broadening 
Table 1. Association Constants $\left(K_{\mathrm{a}}\right), \log \left(K_{\mathrm{a}}\right)$, and Free Energies $(\Delta G)$ for the Formation of 1:1 Bisurea-TBAF Complexes Derived from Bisureas 1 and $2^{a}$

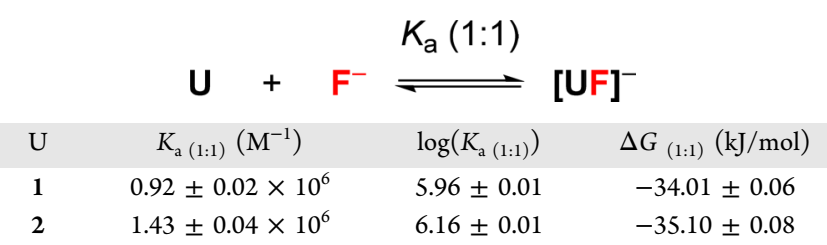

${ }^{a} K_{\mathrm{a}}$ are calculated by nonlinear regression using DynaFit 4 and expressed as the average of two experiments.

in ${ }^{1} \mathrm{H}$ NMR, indicating on-off equilibration. Sharp spectra were gradually recovered when approaching 1 equiv of added fluoride. Noticeable changes in ${ }^{1} \mathrm{H}$ and ${ }^{19} \mathrm{~F}$ chemical shifts were observed between 0 and 1 equiv, after which the chemical shift of all resonances became invariant. Over the course of the titration, proton signals were shielded between 0 and 0.5 equiv of fluoride and deshielded between 0.5 and 1.0 equiv before reaching a plateau at $>1$ equiv. A signal assigned to $\mathrm{NH}(\mathrm{a})$ appeared in ${ }^{1} \mathrm{H}$ NMR at 13.5 ppm after 1 equiv of fluoride was added, while $\mathrm{NH}(\mathrm{b})$ was observed at $7.6 \mathrm{ppm}$ (Figure 6, left). Addition of TBAF to 2 also led to line broadening until quantitative binding was reached. At 1 equiv of fluoride, all $\mathrm{NH}$ are deshielded by $\sim 5 \mathrm{ppm}$ with respect to unbound bisurea 2 (Figure 6, right). The titration of both catalysts 1 and 2 reflects a scenario not limited to $1: 1$ complexation. ${ }^{17}$ More likely, a dimeric species or higher coordinated fluorides dominate at low $\mathrm{F}^{-}$concentration, which then equilibrate toward the more stable $[\mathrm{UF}]^{-} 1: 1$ complex $(\mathrm{U}=1$ or 2$)$ over the course of the titration $\left(K_{\mathrm{a}(1: 1)} \gg K_{\mathrm{a}(2: 1)}\right)$. The variation of chemical shift for diagnostic resonances was plotted against the concentration of added fluoride, and the data were analyzed. Initial attempts to fit the data to a 1:1 binding mode resulted in poor fit and nonsensical data. When a 2:1 binding mode was considered and $K_{\mathrm{a}(1: 1)}$ values secured from UV titration were taken into account, a good agreement with the experimental data was found. This allowed the calculation of 2:1 binding associations $K_{\mathrm{a}(2: 1)}\left(\sim 10^{3} \mathrm{M}^{-1}\right)$ and binding energies for both 1 and 2 (Table 2). In our previous report on diarylurea-fluoride

Table 2. Association Constant $\left(K_{\mathrm{a}}\right), \log \left(K_{\mathrm{a}}\right)$, and Free Energies $(\Delta G)$ for the Formation of 2:1 Bisurea-TBAF Complexes $^{a}$

\begin{tabular}{|c|c|c|c|c|}
\hline & [UF] $^{-}$ & U & $K_{\mathrm{a}}(2: 1)$ & {$\left[\mathrm{U}_{2} \mathrm{~F}\right]^{-}$} \\
\hline $\mathrm{U}$ & $K_{\mathrm{a}(2: 1)}\left(\mathrm{M}^{-1}\right)$ & & $\log \left(K_{\mathrm{a}(2: 1)}\right)$ & $\Delta G_{(2: 1)}(\mathrm{kJ} / \mathrm{mol})$ \\
\hline 1 & $600 \pm 100$ & & $2.80 \pm 0.08$ & $-16.0 \pm 0.5$ \\
\hline 2 & $3100 \pm 900$ & & $3.5 \pm 0.1$ & $-20.0 \pm 0.7$ \\
\hline
\end{tabular}

${ }^{a} K_{\mathrm{a}}$ are calculated by nonlinear regression using DynaFit 4 and expressed as the average of two experiments.

complexes $[\mathrm{UF}]^{-}$and $\left[\mathrm{U}_{2} \mathrm{~F}\right]^{-11 \mathrm{~d}}$ the binding constants were 250-500 $\mathrm{M}^{-1}$ for $K_{\mathrm{a}(2: 1)}$ and $12000-85000 \mathrm{M}^{-1}$ for $K_{\mathrm{a}(1: 1)}$. These were measured in $\mathrm{CD}_{3} \mathrm{CN}$, a solvent in which hydrogenbonding interactions are expected to be weaker.
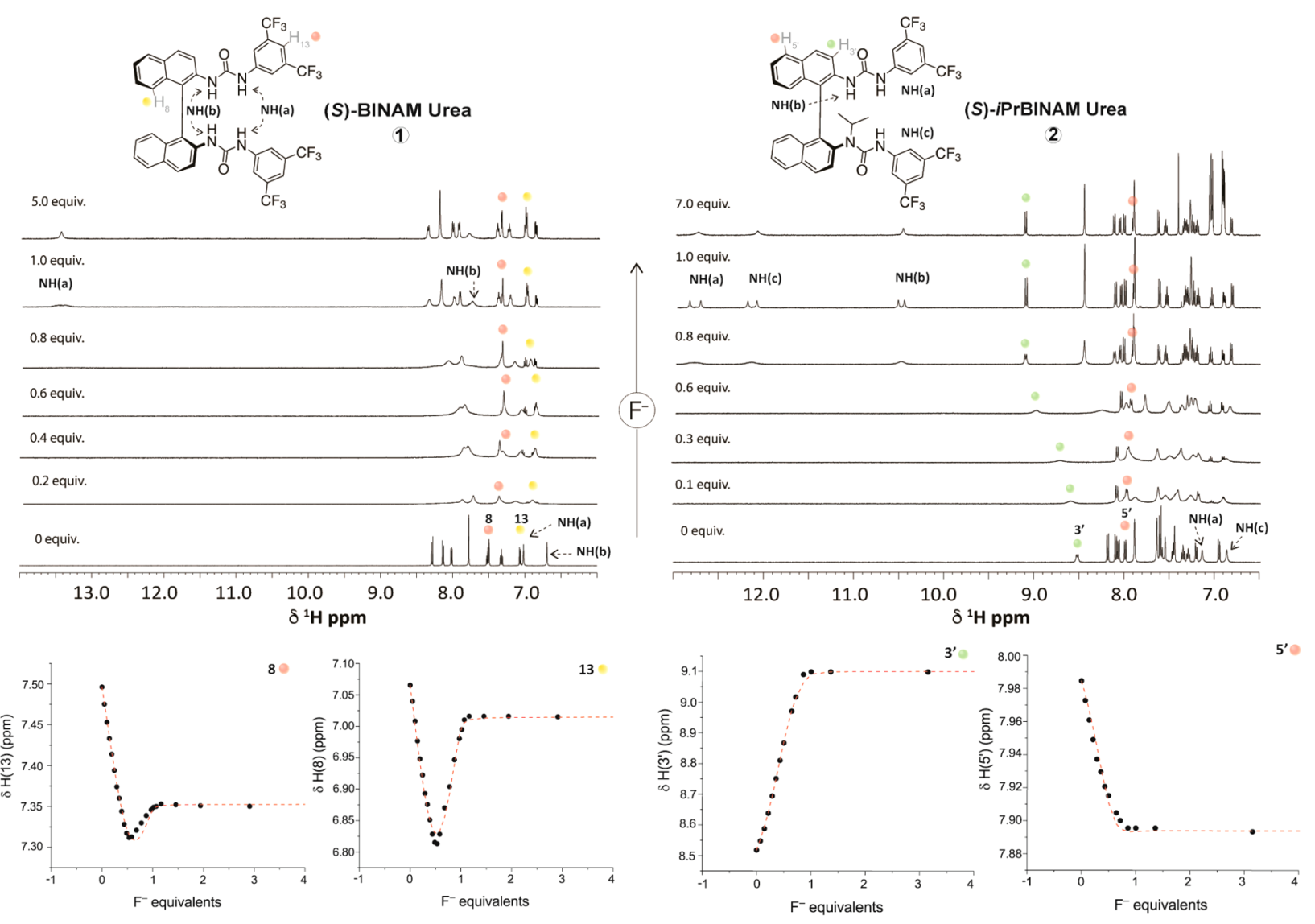

Figure 6. Stacked ${ }^{1} \mathrm{H}$ NMR spectra for the titration of 1 (left) and 2 (right) with TBAF-3 $\mathrm{H}_{2} \mathrm{O}(55 \mathrm{mM})$ in DCM- $d_{2}$ at $298 \mathrm{~K}$. Below, titration profiles for diagnostic protons (black dots) and fitted function (red lines). ${ }^{13}$ 
Hydrogen-Bond Coupling ${ }^{1 \mathrm{~h}} \boldsymbol{J}_{\mathrm{NH} \ldots \mathrm{F}^{-}}$. The three $\mathrm{NH}$ of 2:TBAF are deshielded compared to $2\left(\Delta \delta_{\mathrm{NH}} \approx+5 \mathrm{ppm}\right)$, as are $\mathrm{H}(11), \mathrm{H}\left(11^{\prime}\right)$, and $\mathrm{H}\left(3^{\prime}\right)$. In contrast, $\mathrm{H}(13)$ and $\mathrm{H}\left(13^{\prime}\right)$ on the 3,5-bis(trifluoromethyl)phenyl group, as well as $\mathrm{H}\left(6^{\prime}\right)$, $\mathrm{H}\left(7^{\prime}\right)$, and $\mathrm{H}\left(8^{\prime}\right)$ belonging to naphthyl(I), are shielded. The sharp lines in the ${ }^{1} \mathrm{H}$ and ${ }^{13} \mathrm{C}$ NMR spectra indicate that 2:TBAF is dynamically stable (Figure 7 ).

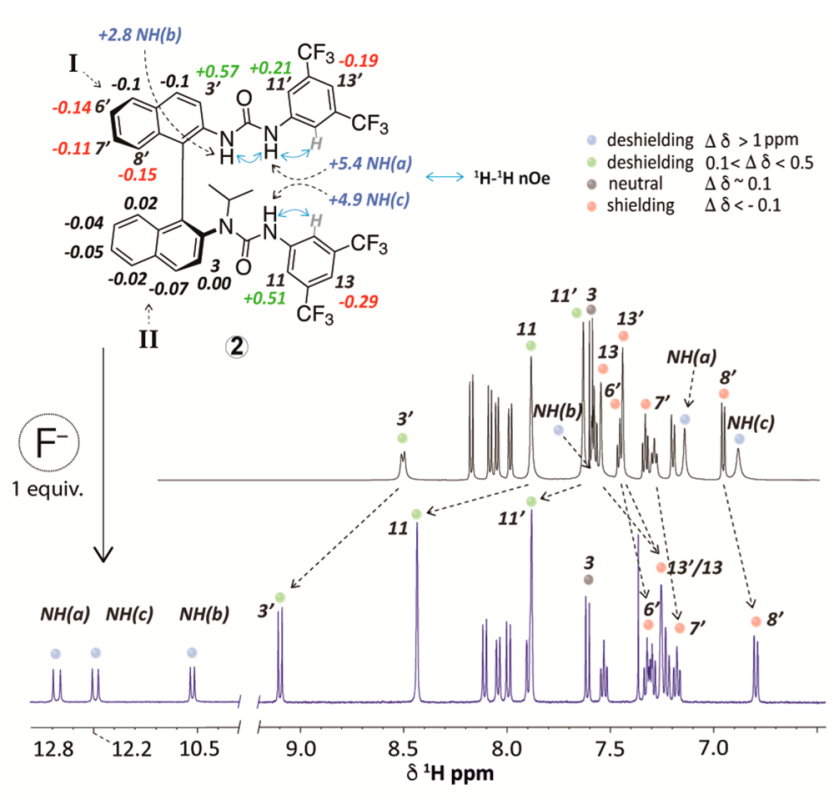

Figure 7. $\delta{ }^{1} \mathrm{H}$ NMR variations of 2 after $\mathrm{F}^{-}$complexation. 2:TBAF was generated by adding 1 equiv of a TBAF $3 \mathrm{H}_{2} \mathrm{O}$ solution $(55 \mathrm{mM}$ in DCM- $\left.d_{2}\right)$ to $2\left(3 \mathrm{mM}\right.$ in DCM- $\left.d_{2}\right)$ at $298 \mathrm{~K}^{13}$

Each $\mathrm{NH}$ appears as a doublet in ${ }^{1} \mathrm{H} \mathrm{NMR}$, and $\mathrm{F}^{-}$appears as a double-double doublet (ddd) in ${ }^{19} \mathrm{~F}$ NMR; the three $\mathrm{NH}$ collapsed into singlets in the fluorine decoupled ${ }^{1} \mathrm{H} \mathrm{NMR}$, and the splitting of the fluoride peak disappeared when ${ }^{19} \mathrm{~F}$ NMR was acquired with proton decoupling. This signal multiplicity represents a case of scalar coupling that develops across hydrogen bonds (hydrogen-bond coupling, HBC). These couplings provide unambiguous proof of hydrogen-bonding interactions between $\mathrm{NH}$ and $\mathrm{F}^{-}$for the complex in solution and a measure of their strength. Because HBC results from overlap of H-bond donor and acceptor wave functions, the magnitude of the coupling depends exponentially on donoracceptor distances, as well as geometry. ${ }^{18}$ Studies by both Grzesiek and Bax demonstrated that the empirical relationship between $\mathrm{HBC}$ and internuclear distances can be exploited for the structural assignment of nucleobases and proteins. ${ }^{19}$ For $\mathrm{HBC}$ to be observable, the hydrogen-bonding network must be rigid, which is often the case for biomolecules held together by multiple hydrogen bonds but is less common in small molecules. ${ }^{20}$ For hydrogen bonds involving the fluoride ion, pioneering work from Shenderovich and Limbach determined ${ }^{1 h} J_{\mathrm{FH}}$ in $\left[\mathrm{F}(\mathrm{HF})_{n}\right]^{-}$clusters measured at ultralow temperature, $^{21}$ while only a few organic molecules such as calix[4]pyrrols and amido cryptand receptors display HBC with fluoride. ${ }^{22}$ The ${ }^{1} \mathrm{H}$ NMR spectrum of 2 :TBAF stands out with three resonances displaying hydrogen-bond scalar couplings with fluoride clearly visible. This offers the possibility of measuring correlation spectra across the hydrogen bridge, a feature more often applied to covalently linked nuclei. The clean in phase-HSQC (CLIP-HSQC) sequence was introduced for the direct measurement of one-bond couplings without phase distortions. ${ }^{23}$ Here, we applied this sequence for ${ }^{1} \mathrm{H}-{ }^{19} \mathrm{~F}$ detection to measure ${ }^{1 \mathrm{~h}} J_{\mathrm{NH} \cdots \mathrm{F}^{-}}$coupling constants, an experiment allowing for the four nuclei involved in the hydrogen-bonding network of 2:TBAF to be observed (Figure 8). The ${ }^{1} \mathrm{H}$ chemical shifts are seen on the horizontal axis, and

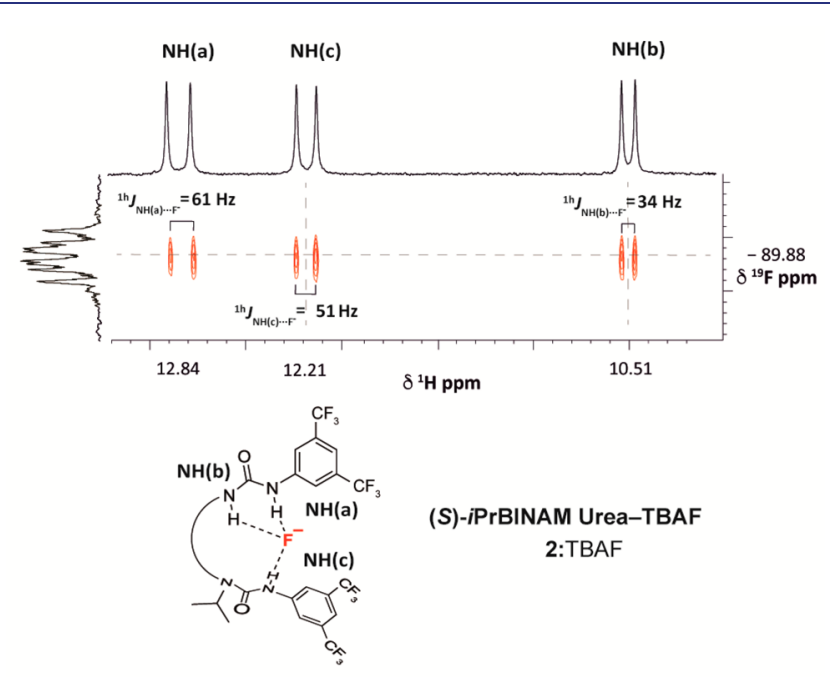

Figure 8. ${ }^{1} \mathrm{H}-{ }^{19} \mathrm{~F}$ CLIP-HSQC of 2:TBAF $\left(500 \mathrm{MHz}, \mathrm{DCM}-d_{2}, 3\right.$ $\mathrm{mM}, 298 \mathrm{~K})$.

the ${ }^{19} \mathrm{~F}$ chemical shift is seen on the vertical axis with the magnitude of ${ }^{1 \mathrm{~h}} \mathrm{~J}_{\mathrm{NH} \ldots \mathrm{F}^{-}}$determined from cross-peak distances (which matched those visible in the ${ }^{1} \mathrm{H}$ spectrum). The three HBC constants measured for 2:TBAF (DCM- $d_{2}, 3 \mathrm{mM}, 298$ K) are ${ }^{1 \mathrm{~h}} J_{\mathrm{NH}(\mathrm{a}) \cdots \mathrm{F}^{-}}=61 \mathrm{~Hz},{ }^{1 \mathrm{~h}} J_{\mathrm{NH}(\mathrm{c}) \cdots \mathrm{F}^{-}}=51 \mathrm{~Hz}$, and ${ }^{1 \mathrm{~h}} J_{\mathrm{NH}(\mathrm{b}) \cdots \mathrm{F}^{-}}$ $=34 \mathrm{~Hz}$.

In DCM- $d_{2}$, the peak of $\mathrm{F}^{-}$at $-90 \mathrm{ppm}$ for 2:TBAF is deshielded compared to TBAF $3 \mathrm{H}_{2} \mathrm{O}$, which resonates at -118 ppm. $^{24}$ The $\mathrm{F}^{-}$longitudinal relaxation time constant $\left(T_{1}\right)$ would be expected to vary upon formation of a hydrogenbonded fluoride complex because $T_{1}$ depends on the motions of the molecule in solution (and hence its size) as well as the proximity of neighboring protons as relaxation sources. Accordingly, $T_{1}$ measured for ${ }^{19} \mathrm{~F}$ via inversion recovery experiments (magnet field strength $=11.7 \mathrm{~T}$ ) was found to decrease from $1430 \mathrm{~ms}$ for TBAF $3 \mathrm{H}_{2} \mathrm{O}$ to $313 \mathrm{~ms}$ for 2:TBAF, which is consistent with the formation of a larger, $\mathrm{H}$ bonded molecular complex. The magnitude of the HBC constant for each $\mathrm{NH}$ inversely correlates with the $\mathrm{NH} \cdots \mathrm{F}$ internuclear distance measured from the solid-state structure of 2:TBAF (determined by single-crystal X-ray diffraction), with $\mathrm{NH}(\mathrm{a}) \cdots \mathrm{F}^{-}$being the shortest $\mathrm{HB}$ contact with fluoride. To correlate ${ }^{\mathrm{lh}} \mathrm{J}_{\mathrm{NH} \cdots \mathrm{F}^{-}}$and hydrogen-bond distances in solution, the NOE developed between fluoride and $\mathrm{NH}$ was investigated by ${ }^{1} \mathrm{H}-{ }^{19} \mathrm{~F}$ heteronuclear Overhauser spectroscopy (HOESY). NOE buildup curves were determined using mixing times between 10 and $600 \mathrm{~ms}$, and $\mathrm{NH}-\mathrm{F}$ distances relative to $\mathrm{NH}(\mathrm{a})-\mathrm{F}$ were calculated (Figure 9$).{ }^{13}$ The distance of $\mathrm{NH}$ to fluoride increased in the following order: $\mathrm{NH}(\mathrm{a}) \approx \mathrm{NH}(\mathrm{c})<$ $\mathrm{NH}(\mathrm{b})$, with $\mathrm{NH}(\mathrm{c}) \cdots \mathrm{F}^{-}$being $2 \%$ longer than $\mathrm{NH}(\mathrm{a}) \cdots \mathrm{F}^{-}$, and $\mathrm{NH}(\mathrm{b}) \cdots \mathrm{F}^{-}$being $12 \%$ longer. Larger coupling constants ${ }^{1 \mathrm{~h}} \mathrm{~J}_{\mathrm{NH} \cdots \mathrm{F}^{-}}$therefore correspond to shorter $\mathrm{HB}$ distance. An additional NOE correlation between the ortho-aromatic proton $\mathrm{H}(11)$ with fluoride was observed, although of smaller 


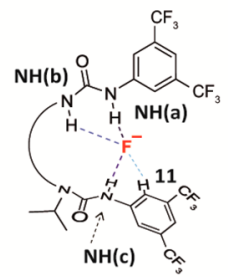

\begin{tabular}{lccc}
\multicolumn{4}{c}{$\mathrm{H}-\mathrm{F}$ distance relative to $\mathrm{H}(\mathrm{a})-\mathrm{F}^{-}=1.00$} \\
$\mathrm{NMR}$ (HOESY) & X-ray & ${ }^{1 \mathrm{~h}} \mathrm{NH}_{\mathrm{NH}-\mathrm{F}^{-}}[\mathrm{Hz}]$ \\
$\mathrm{NH}(\mathrm{a})-\mathrm{F}^{-}$ & 1.00 & 1.00 & 61 \\
$\mathrm{NH}(\mathrm{c})-\mathrm{F}^{-}$ & 1.02 & 1.01 & 51 \\
$\mathrm{NH}(\mathrm{b}) \mathrm{F}^{-}$ & 1.12 & 1.03 & 34 \\
$\mathrm{CH}(11)-\mathrm{F}^{-}$ & 1.54 & 1.27 & -
\end{tabular}

Figure 9. Relative $\mathrm{H} \cdots \mathrm{F}^{-}$distances calculated for 2:TBAF from HOESY (DCM- $d_{2}, 10 \mathrm{mM}, 298 \mathrm{~K}, \tau_{\mathrm{m}}=10-600 \mathrm{~ms}$ ) and comparison with single-crystal X-ray diffraction and ${ }^{1 \mathrm{~h}} J_{\mathrm{NH} \cdots \mathrm{F}^{-}}$.

magnitude. Taken together, these data concur with the relative distances seen in the solid state from single-crystal X-ray diffraction studies, although the values for $\mathrm{NH}(\mathrm{b}) \cdots \mathrm{F}^{-}$and $\mathrm{H}(11) \cdots \mathrm{F}^{-}$are shorter than those from solution studies.

Next, we studied $N$-isopropyl bisurea 13 featuring 3,5difluorophenyl groups as this substituent features vicinal hydrogen and fluorine of known distance $(2.60 \AA){ }^{25}$ Similarly to 2 :TBAF, the distances in 13:TBAF calculated from HOESY experiments with a single mixing time of $30 \mathrm{~ms}$, were found to be inversely proportional to the size of the $\mathrm{HB}$ coupling constants (absolute distance for $\mathrm{NH}(\mathrm{a}) \cdots \mathrm{F}^{-}=1.83 \AA$, $\mathrm{NH}(\mathrm{c}) \cdots \mathrm{F}^{-}=1.91 \AA$, and $\mathrm{NH}(\mathrm{b}) \cdots \mathrm{F}^{-}=2.05 \AA$ ) (Figure 10).
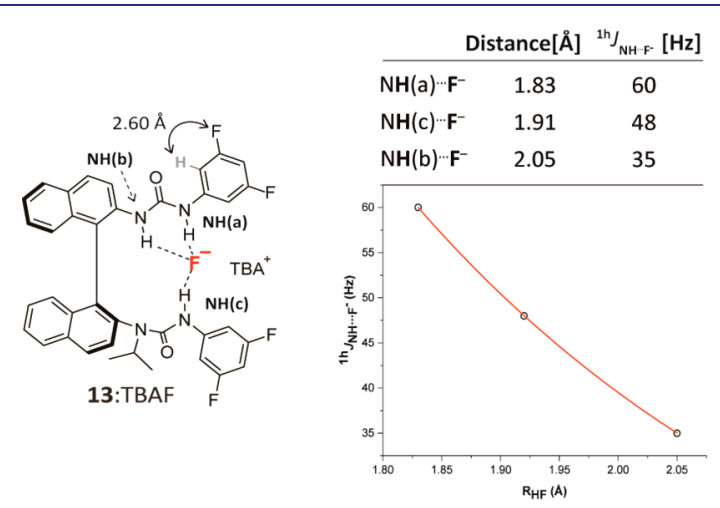

Figure 10. Quantitative ${ }^{1} \mathrm{H}-{ }^{19} \mathrm{~F}$ HOESY of 13:TBAF (DCM- $d_{2}, 3$ $\mathrm{mM}, 298 \mathrm{~K}, \tau_{\mathrm{m}}=30 \mathrm{~ms}$ ).

To gain insight into the conformational preference of 2:TBAF, ${ }^{1} \mathrm{H}$ NOESY cross-peak volumes were converted into absolute distances by calibration with the distance of the vicinal protons $\mathrm{H}\left(3^{\prime}\right)$ and $\left.\mathrm{H}\left(4^{\prime}\right)(2.47 \AA)\right)^{25}$ This allowed for a quantitative mapping analysis of $\mathrm{H}-\mathrm{H}$ internuclear distances for 2:TBAF (Figure 11A). ${ }^{26}$ Correlation $\mathrm{H}(16) \Leftrightarrow \mathrm{H}\left(8^{\prime}\right)$ indicates that the isopropyl $\mathrm{C}-\mathrm{H}$ bond points toward naphthyl(I) with a distance between the two protons of 2.6 $\AA$. In contrast to unbound bisurea 2 , the protons belonging to the $N$-iPr group do not correlate with $\mathrm{NH}(\mathrm{c})$, which instead shows two NOE with $\mathrm{H}(11)$ and $\mathrm{NH}(\mathrm{b})$ (2.7 and $2.5 \AA$ ), suggesting that the $\mathrm{N}$-isopropyl urea underwent an anti-anti to syn-anti conformational change upon fluoride binding. $\mathrm{NH}(\mathrm{a})$ and $\mathrm{NH}(\mathrm{b})$ belonging to the same urea display strong NOE $(2.0 \AA) . \mathrm{NH}(\mathrm{a})$ also presents correlation with $\mathrm{H}\left(11^{\prime}\right)$ $(2.7 \AA)$ and $\mathrm{H}(11)(3.5 \AA)$. These NOE interactions indicate that the three $\mathrm{NH}$ are in close proximity. Deshielding of $\mathrm{H}\left(3^{\prime}\right)$ upon fluoride binding indicates more pronounced coplanarity between $\mathrm{H}\left(3^{\prime}\right)$ and the adjacent urea carbonyl with respect to unbound 2 . The internuclear distances measured by NMR are

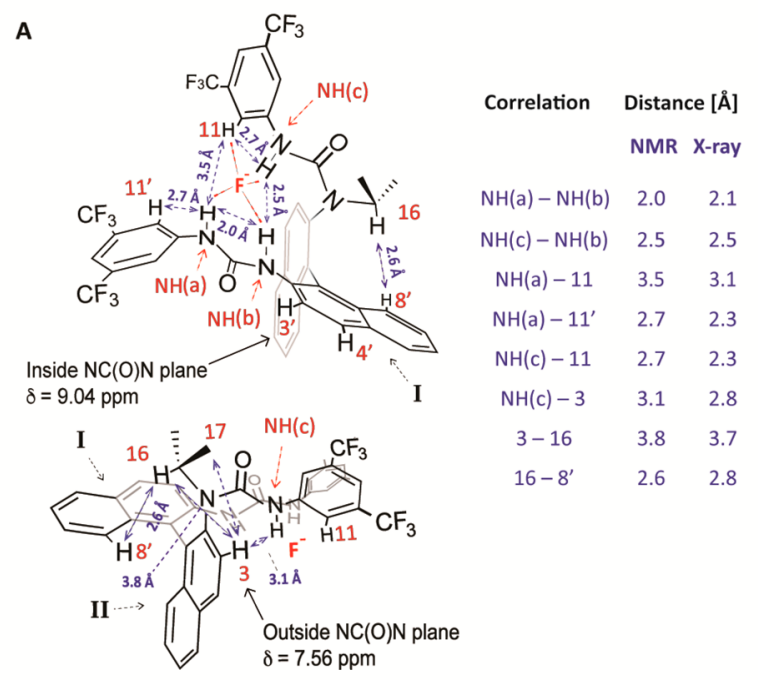

.

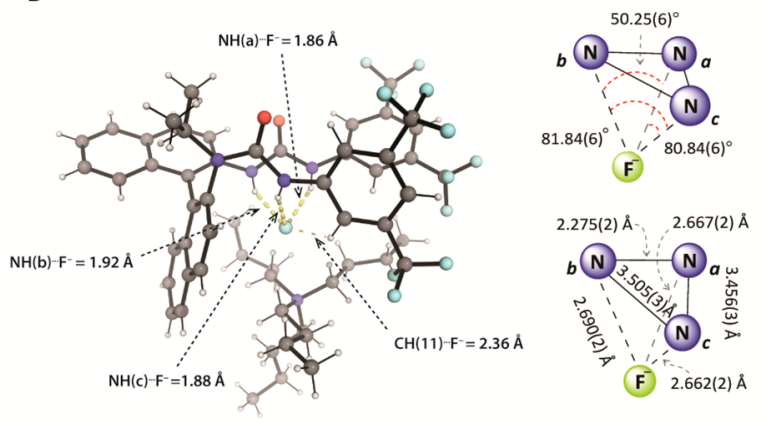

Figure 11. (A) Structure of 2:TBAF and internuclear distances calculated from ${ }^{1} \mathrm{H}$ NOESY $\left(600 \mathrm{MHz}, \mathrm{DCM}-d_{2}, 3 \mathrm{mM}, 298 \mathrm{~K}, \tau_{\mathrm{m}}=\right.$ $300 \mathrm{~ms}$ ) and comparison with X-ray structure data. (B) Solid-state structure from single-crystal X-ray diffraction studies of 2:TBAF.

in keeping with those determined for the solid-state structure using single-crystal X-ray diffraction (Figure 11B).

${ }^{1 \mathrm{~h}} \mathrm{JHH}_{\mathrm{NH}}$ - Studies of Bisurea-TBAF Complexes. With a robust NMR experiment correlating ${ }^{1 \mathrm{~h}} \mathrm{~J}_{\mathrm{NH} \cdots \mathrm{F}^{-}}$and internuclear distances in place, we studied how fluoride positioned itself within the pocket of a range of BINAM-derived bisurea catalysts. Thirteen complexes were formed by addition of 1 equiv of TBAF $3 \mathrm{H}_{2} \mathrm{O}$ to a solution of bisurea, and the coupling constants ${ }^{\mathrm{lh}} \mathrm{J}_{\mathrm{NH} \cdots \mathrm{F}^{-}}$were measured. For each catalyst-fluoride complex, ${ }^{1} \mathrm{H}$ NMR, ${ }^{19} \mathrm{~F}$ NMR, and CLIP-HSQC were recorded at $273 \mathrm{~K}$ and at low concentration $(3 \mathrm{mM})$ to minimize proton exchange with water, which we had observed to mask ${ }^{\mathrm{lh}} J$ couplings via spin-exchange decoupling. Complexation of nonalkylated BINAM bisurea 1 with TBAF-3 $\mathrm{H}_{2} \mathrm{O}$ led to deshielding of all $\mathrm{NH}$ resonances indicative of fluoride binding, but no coupling with fluoride was observed at $3 \mathrm{mM}$. At lower concentration $(0.58 \mathrm{mM}), \mathrm{HBC}$ was observed for the pair of equivalent $\mathrm{NH}(\mathrm{a})$ linked to 3,5-bis(trifluoromethyl)phenyl with ${ }^{1 \mathrm{~h}} J_{\mathrm{NH}(\mathrm{a}) \ldots \mathrm{F}^{-}}=65 \mathrm{~Hz}$, and $\Delta \delta_{\mathrm{NH}(\mathrm{a})}=+6$ ppm compared to unligated 1 (Figure 12). ${ }^{13}$

This dependence on concentration suggests a higher rate of proton exchange with water compared to 2 :TBAF. Faster onoff fluoride complexation could also be responsible for the line broadening observed at a higher concentration. In ${ }^{19} \mathrm{~F}$ NMR, fluoride appears as a triplet at $-86 \mathrm{ppm}$. The $\mathrm{NH}(\mathrm{b})$ pair is only slightly deshielded upon fluoride complexation, $\Delta \delta_{\mathrm{NH}(\mathrm{b})}=$ $+1 \mathrm{ppm}$. The number of proton signals indicate that 1 :TBAF 


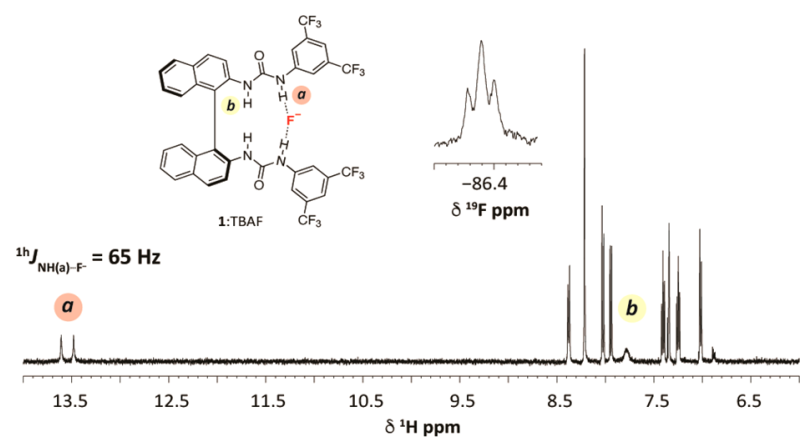

Figure 12. ${ }^{1} \mathrm{H}$ NMR of $1: T B A F\left(D C M-d_{2}, 0.58 \mathrm{mM}, 273 \mathrm{~K}\right.$ ); (inset) ${ }^{19} \mathrm{~F}$ NMR of 1 :TBAF showing fluoride splitting.

retains its $C_{2}$ symmetry. Taken together, these observations suggest that 1 in DCM- $d_{2}$ forms a bidentate complex with fluoride bound to $\mathrm{NH}(\mathrm{a})$ away from the binaphthyl system. Catalysts 3-7 that are N-alkylated with different hydrocarbon chains display ${ }^{1 \mathrm{~h}} \mathrm{~J}_{\mathrm{NH} \cdots \mathrm{F}^{-}}$values between $59-61 \mathrm{~Hz}$ for $\mathrm{NH}(\mathrm{a})$, $48-54 \mathrm{~Hz}$ for $\mathrm{NH}(\mathrm{c})$, and $33-34 \mathrm{~Hz}$ for $\mathrm{NH}(\mathrm{b})$, which are highly similar to those for 2 :TBAF (Table 3, entries 3-7). $\mathrm{NH}(\mathrm{c}) \cdots \mathrm{F}^{-}$varies the most with a difference of up to $6 \mathrm{~Hz}$ for ${ }^{1 h} J_{\mathrm{NH} \cdots \mathrm{F}^{-}}$. A series of $\mathrm{N}$-isopropyl bisurea-fluoride complexes with different 3,5-substituted aromatic rings was examined next. Electron-poor aryl groups are expected to increase $\mathrm{NH}$ acidity and therefore hydrogen-bond strength with fluoride; conversely, electron-rich aromatic rings would weaken $\mathrm{NH}_{\cdots} \mathrm{F}^{-}$ hydrogen-bonding interactions. This offers a platform to control the positioning of fluoride within the catalyst pocket, possibly tune its nucleophilicity, and influence the enantioselective delivery. Catalysts $8\left(R_{1}=H, R_{2}=C_{3}\right)$ and $11\left(R_{1}=\right.$ $\left.\mathrm{F}, \mathrm{R}_{2}=\mathrm{CF}_{3}\right)$ resulted in ${ }^{1 \mathrm{~h}} \mathrm{~J}_{\mathrm{NH}(\mathrm{c}) \cdots \mathrm{F}^{-}}$values of 39 and $44 \mathrm{~Hz}$, respectively, indicating reduced interaction between $\mathrm{NH}(\mathrm{c})$ and fluoride (Table 3, entries 8 and 11). Catalysts $9\left(R_{1}=C F_{3}\right.$,
$\left.\mathrm{R}_{2}=\mathrm{H}\right), \mathbf{1 0}\left(\mathrm{R}_{1}=\mathrm{CF}_{3}, \mathrm{R}_{2}=\mathrm{Me}\right)$, and $12\left(\mathrm{R}_{1}=\mathrm{CF}_{3}, \mathrm{R}_{2}=\mathrm{F}\right)$ displayed weaker hydrogen bonding between fluoride and $\mathrm{NH}(\mathrm{a})$, with ${ }^{1 \mathrm{~h}} J_{\mathrm{NH}(\mathrm{c}) \cdots \mathrm{F}^{-}}$values increased and even exceeding ${ }^{1 h} J_{\mathrm{NH}(\mathrm{a}) \cdots \mathrm{F}^{-}}$for $\mathbf{1 0}$ (Table 3, entries 9, 10, and 12). Fluoride is equally shared between $\mathrm{NH}(\mathrm{a})$ and $\mathrm{NH}(\mathrm{c})$ for 9 and $\mathbf{1 0}$ despite the electronic character of the rings expected to favor $\mathrm{NH}(\mathrm{c})$. Catalyst $13\left(\mathrm{R}_{1}=\mathrm{R}_{2}=\mathrm{F}\right)$ presents similar ${ }^{1 \mathrm{~h}} J$ values to 2 for $\mathrm{NH}(\mathrm{a})$ and $\mathrm{NH}(\mathrm{b})$ but a more pronounced variation in $\mathrm{NH}(\mathrm{c})$, which is reduced by $4 \mathrm{~Hz}$ (Table 3 , entry 13 ).

These data are informative at various levels:

- In solution, all three $\mathrm{NH}$ of $\mathrm{N}$-alkylated bisurea catalysts bind fluoride with the $\mathrm{N}$-alkylated urea undergoing anti-anti to syn-anti isomerization. This contrasts with the nonalkylated catalyst 1, which does not engage all four $\mathrm{NH}$ groups in hydrogen bonding with fluoride; the two $\mathrm{NH}$ bound to fluoride are the ones substituted by the trifluoromethylated aryl groups, and ${ }^{1 \mathrm{~h}} J$ values are of large magnitude $(65 \mathrm{~Hz})$. Complex 1:TBAF is less dynamically stable than 2 :TBAF as reflected by the broad line and unresolved ${ }^{\mathrm{lh}} J$ coupling at 3 $\mathrm{mM}$ concentration.

- For all catalysts, $\mathrm{NH}(\mathrm{a}) \cdots \mathrm{F}^{-}$is the dominant hydrogenbonding interaction in DCM- $d_{2}$, even when programmed to be weaker by tuning its electronic environment; this is likely due to more favorable geometrical arrangement for hydrogen bonding. $\mathrm{NH}(\mathrm{c}) \cdots \mathrm{F}^{-}$is the hydrogen bond that varies the most, and $\mathrm{NH}(\mathrm{b})$ provides the weakest $\mathrm{HB}$ contribution with ${ }^{\mathrm{lh}} J$ values of $33-34 \mathrm{~Hz}$.

- The complexes display ${ }^{19} \mathrm{~F}$ chemical shifts between -86 and $-94 \mathrm{ppm}$, which represents a deshielding of $\sim 30 \mathrm{ppm}$ compared to unbound TBAF $3 \mathrm{H}_{2} \mathrm{O}$ in DCM- $\hat{d}_{2}$. ${ }^{27}$

Complexation with CsF. Fluorinations under HB-PTC are carried out with alkali metal fluorides (MFs), requiring the formation of a soluble bisurea-MF complex as a reaction intermediate. The spectroscopic characterization of a representative bisurea-MF complex would therefore provide

Table 3. HBC Constants ${ }^{1 \mathrm{~h}} \mathrm{~J}_{\mathrm{NH} \cdots \mathrm{F}^{-}}$and ${ }^{19} \mathrm{~F}$ Chemical Shifts of Bisurea-Fluoride Complexes ${ }^{a}$

\begin{tabular}{|c|c|c|c|c|c|c|c|c|}
\hline entry & catalyst & $\mathrm{R}$ & $\mathrm{R}_{1}$ & $\mathrm{R}_{2}$ & ${ }^{1 \mathrm{~h}} J_{\mathrm{NH}(\mathrm{a}) \cdots \mathrm{F}^{-}}(\mathrm{Hz})$ & ${ }^{\mathrm{lh}} J_{\mathrm{NH}(\mathrm{c}) \cdots \mathrm{F}^{-}}(\mathrm{Hz})$ & ${ }^{\mathrm{lh}} J_{\mathrm{NH}(\mathrm{b}) \cdots \mathrm{F}^{-}}(\mathrm{Hz})$ & $\delta{ }^{19} \mathrm{~F}(\mathrm{ppm})$ \\
\hline $1^{b}$ & 1 & $\mathrm{H}$ & & & 65 & & & -86.40 \\
\hline 2 & 2 & $i \operatorname{Pr}$ & & & 60 & 50 & 33 & -90.53 \\
\hline 3 & 3 & $\mathrm{Me}$ & & & 60 & 54 & 34 & -89.41 \\
\hline 4 & 4 & Et & & & 61 & 54 & 34 & -88.64 \\
\hline 5 & 5 & $n \operatorname{Pr}$ & & & 60 & 53 & 33 & -88.79 \\
\hline 6 & 6 & $c$ Pentyl & & & 59 & 48 & 34 & -91.33 \\
\hline 7 & 7 & 3-Pentyl & & & 61 & 52 & 34 & -89.20 \\
\hline 8 & 8 & $i \operatorname{Pr}$ & $\mathrm{H}$ & $\mathrm{CF}_{3}$ & 63 & 39 & 34 & -93.87 \\
\hline 9 & 9 & $i \operatorname{Pr}$ & $\mathrm{CF}_{3}$ & $\mathrm{H}$ & 53 & 52 & 33 & -93.87 \\
\hline 10 & 10 & $i \operatorname{Pr}$ & $\mathrm{CF}_{3}$ & $\mathrm{Me}$ & 52 & 53 & 34 & -90.15 \\
\hline 11 & 11 & $i \operatorname{Pr}$ & $\mathrm{F}$ & $\mathrm{CF}_{3}$ & 60 & 44 & 33 & -89.79 \\
\hline 12 & 12 & $i \operatorname{Pr}$ & $\mathrm{CF}_{3}$ & $\mathrm{~F}$ & 59 & 51 & 33 & -91.59 \\
\hline 13 & 13 & $i \operatorname{Pr}$ & & & 59 & 46 & 34 & -91.17 \\
\hline
\end{tabular}

${ }^{a_{T}}$ The fluoride complexes were generated by addition of 1 equiv of TBAF· $3 \mathrm{H}_{2} \mathrm{O}$ (solution in DCM- $d_{2}$ of known concentration) to the bisurea ( 3 $\mathrm{mM}$ in DCM- $d_{2}$ ) and measured at $273 \mathrm{~K} .{ }^{b} \mathrm{In}$ DCM/DCM- $d_{2}, 0.58 \mathrm{mM}$. 
valuable information. With the prospect of carrying out ${ }^{133} \mathrm{Cs}$ NMR, we selected 2:CsF for this study. Because of the limited solubility of CsF, the complex was generated in a sealed NMR tube by sonication of $\mathrm{N}$-isopropylated bisurea 2 and solid CsF (50 equiv) in DCM- $d_{2}(25 \mathrm{mM}) .{ }^{13}$ The ${ }^{1} \mathrm{H}$ NMR spectrum at room temperature showed extensive line broadening, indicating that equilibration of several species took place. Lowtemperature experiments $(298-243 \mathrm{~K})$ gave three sets of signals diagnostic for isopropyl $\mathrm{H}(16)$; these were in mutual chemical exchange as revealed by the sign of ROESY crosspeaks. The presence of at least seven $\mathrm{NH}$ doublets denoted the presence of multiple species in solution (Figure 13). The ${ }^{19} \mathrm{~F}$

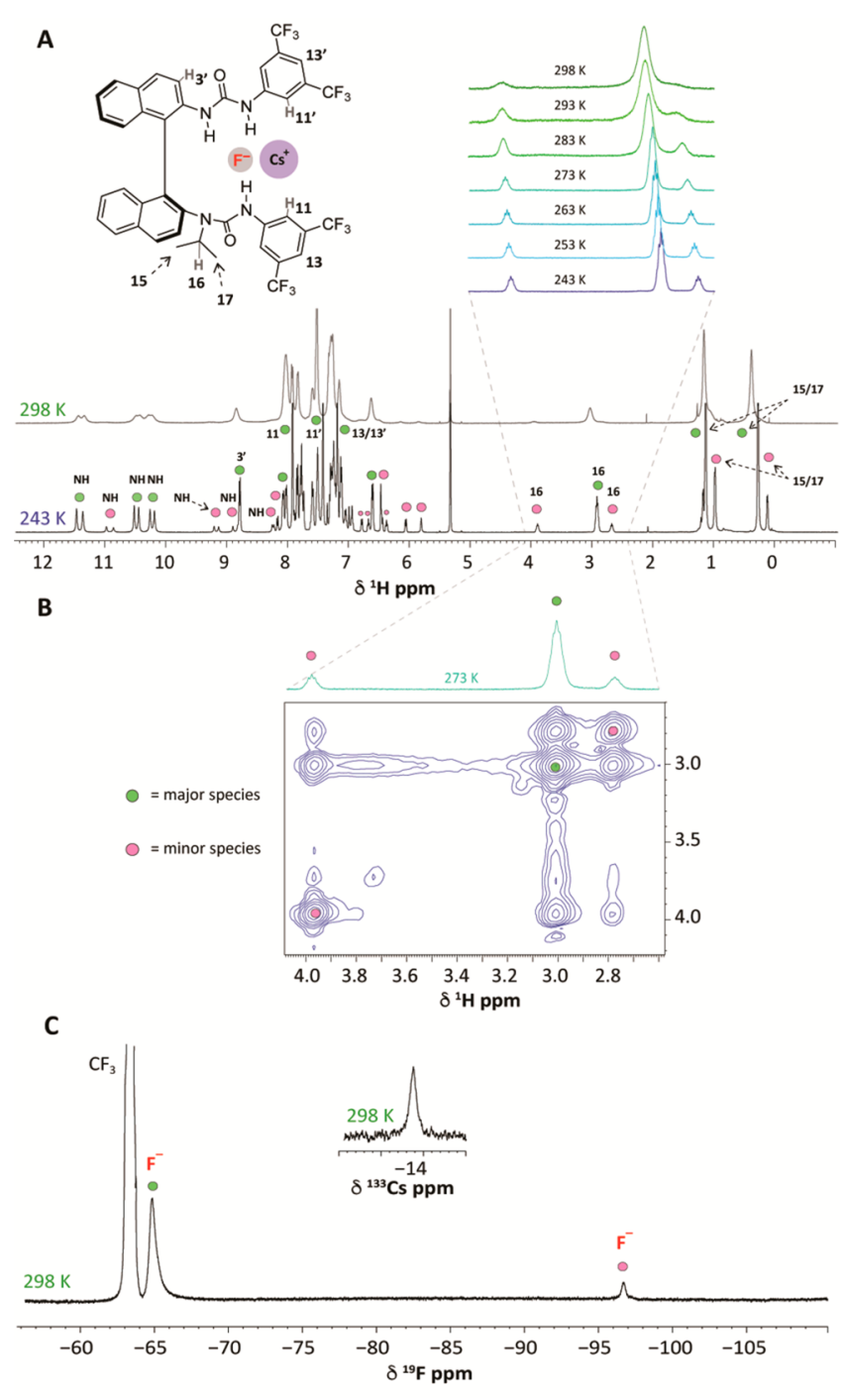

Figure 13. (A) ${ }^{1} \mathrm{H}$ NMR after mixing 2 with CsF (DCM- $\left.d_{2}, 25 \mathrm{mM}\right)$ recorded at $298 \mathrm{~K}$ (overlaid, gray line) and $243 \mathrm{~K}$ (black line); (B) detail of ROESY spectrum recorded at $273 \mathrm{~K}$ showing chemical exchange cross-peaks; (C) ${ }^{19} \mathrm{~F}$ NMR and ${ }^{133} \mathrm{Cs}$ NMR (inset).

NMR spectrum (298-243 K) showed two signals, with the major resonating at $-65 \mathrm{ppm}$ and the minor resonating at -96 ppm (Figure $13 \mathrm{C}$ ). $T_{1}$ relaxation was measured by inversion recovery experiments for both fluoride resonances at room temperature (magnet field strength $11.7 \mathrm{~T}$ ) and found to be 145 and $5 \mathrm{~ms}$ for the major and minor species, respectively. These $T_{1}$ values are substantially shorter than those of 2 :TBAF (313 ms) and TBAF in DCM- $d_{2}(1430 \mathrm{~ms})$, suggesting slower tumbling due to the species in solution being larger in size and/or increased contributions from local relaxation sources. ${ }^{133}$ Cs NMR shows a wide peak (Figure $13 \mathrm{C}$, inset) broadened as a result of its quadrupolar moment, as well as dynamic averaging of more than one cesium fluoride complex. The ${ }^{133} \mathrm{Cs}$ signal is recorded at $-14 \mathrm{ppm}$ at room temperature, which is significantly more shielded than previously observed for the ion pair formed from $\mathrm{Cs}^{+}$and the weakly coordinating $\left[\mathrm{H}_{2} \mathrm{NB}_{2}\left(\mathrm{C}_{6} \mathrm{~F}_{5}\right)_{6}\right]^{-}$anion (17 ppm), a rare example of ${ }^{133} \mathrm{Cs}$ NMR for a Cs ${ }^{+}$salt measured in DCM- $d_{2}{ }^{28}$

Proton diffusion experiments ( ${ }^{1} \mathrm{H}$ DOSY) were performed at $243 \mathrm{~K}$ and revealed that the three sets of peaks assigned to isopropyl $\mathrm{CH}(16)$ belong to two species. The minor species had a smaller diffusion coefficient $\left(D=1.9 \times 10^{-10} \mathrm{~m}^{2} \mathrm{~s}^{-1}\right)$, denoting a larger molecular complex, while the major species displayed faster diffusion $\left(D=2.4 \times 10^{-10} \mathrm{~m}^{2} \mathrm{~s}^{-1}\right) .{ }^{13}$ These data support the presence of a 1:1 bisurea-fluoride complex as the major species and a minor nonsymmetrical 2:1 complex. ${ }^{19} \mathrm{~F}$ NMR indicated that the $1: 1$ to $2: 1$ ratio was $85: 15$ at room temperature.

The NH signals for both species were unambiguously identified using NOESY (EXSY) and ROESY correlations (measured, respectively, at 273 and $243 \mathrm{~K}$ ); ${ }^{1 \mathrm{~h}} \mathrm{~J}_{\mathrm{NH} \cdots \mathrm{F}^{-}}$coupling constants together with ${ }^{1} \mathrm{H}-{ }^{19} \mathrm{~F}$ NOE gave insight into binding modes. The chemical shifts for the $\mathrm{NH}$ protons of the 1:1 complex (2:CsF) were comparable to those observed for 2:TBAF, with $\mathrm{NH}(\mathrm{a})$ being the most deshielded $\left(\delta_{\mathrm{NH}(\mathrm{a})}=\right.$ $11.46 \mathrm{ppm})$, followed by $\mathrm{NH}(\mathrm{c})\left(\delta_{\mathrm{NH}(\mathrm{c})}=10.52 \mathrm{ppm}\right)$ and $\mathrm{NH}(\mathrm{b})\left(\delta_{\mathrm{NH}(\mathrm{b})}=10.26 \mathrm{ppm}\right)$. Complex 2:CsF displayed ${ }^{1 \mathrm{~h}} J_{\mathrm{NH} \cdots \mathrm{F}^{-}}$splitting of $52 \mathrm{~Hz}$ for $\mathrm{NH}(\mathrm{a}), 37 \mathrm{~Hz}$ for $\mathrm{NH}(\mathrm{c})$, and $34 \mathrm{~Hz}$ for $\mathrm{NH}(\mathrm{b})$. These values differ from those for 2:TBAF, which shows larger $\mathrm{HB}$ coupling constants for both $\mathrm{NH}(\mathrm{a})$ and $\mathrm{NH}$ (c) (cf. 2:TBAF: ${ }^{1 \mathrm{~h}} \mathrm{~J}_{\mathrm{NH}(\mathrm{a}) \cdots \mathrm{F}^{-}}=61 \mathrm{~Hz},{ }^{1 \mathrm{~h}} J_{\mathrm{NH}(\mathrm{c}) \cdots \mathrm{F}^{-}}=51 \mathrm{~Hz}$, and ${ }^{1 \mathrm{~h}} \mathrm{~J}_{\mathrm{NH}(\mathrm{b}) \cdots \mathrm{F}^{-}}=34 \mathrm{~Hz}$, measured at $\left.298 \mathrm{~K}\right) .{ }^{1 \mathrm{~h}} J_{\mathrm{NH}(\mathrm{c}) \cdots \mathrm{F}^{-}}$stands out for being reduced by $14 \mathrm{~Hz}$. The $2: 1$ complex Cs $\left[(2)_{2}: \mathrm{F}\right]$ shows five NH$\cdots \mathrm{F}$ correlations in ${ }^{1} \mathrm{H}-{ }^{19} \mathrm{~F}$ CLIP-HSQC and ${ }^{1} \mathrm{H}-{ }^{19} \mathrm{~F}$ HOESY. In $\mathrm{Cs}\left[(2)_{2}: \mathrm{F}\right]$, one of the two bisureas exhibited tridentate binding to fluoride $\left({ }^{1 \mathrm{~h}} \mathrm{~J}_{\mathrm{NH}(\mathrm{a}) \cdots \mathrm{F}^{-}}=40 \mathrm{~Hz}\right.$, ${ }^{1 \mathrm{~h}} \mathrm{~J}_{\mathrm{NH}(\mathrm{b}) \cdots \mathrm{F}^{-}}=37 \mathrm{~Hz}$, and ${ }^{1 \mathrm{~h}} J_{\mathrm{NH}(\mathrm{c}) \cdots \mathrm{F}^{-}}=14 \mathrm{~Hz}$ ), while the other featured two $\mathrm{HB}$ contacts engaging its nonalkylated urea submotif $\left({ }^{1 h} J_{\mathrm{NH}(\mathrm{a})^{\prime} \cdots \mathrm{F}^{-}}=58 \mathrm{~Hz}\right.$ and $\left.{ }^{1 \mathrm{~h}} J_{\mathrm{NH}(\mathrm{b})^{\prime} \cdots \mathrm{F}^{-}}=21 \mathrm{~Hz}\right)$. $\mathrm{NH}(\mathrm{c})^{\prime}$ appeared as a shielded singlet at $5.8 \mathrm{ppm}$ and did not interact with fluoride (Figure 14).

We noted important differences in fluoride chemical shifts. The observed shifts were -96 and $-65 \mathrm{ppm}$ for $\mathrm{Cs}\left[(2)_{2}: \mathrm{F}\right]$ and 2:CsF, respectively. This large difference suggests no interaction between fluoride and $\mathrm{Cs}^{+}$in $\mathrm{Cs}\left[(\mathbf{2})_{2}: \mathrm{F}\right]$; in contrast, for 2:CsF, $\mathrm{Cs}^{+}$likely forms a contact ion pair with $\mathrm{F}^{-}$in $\mathrm{DCM}-d_{2}$. No data are available in the literature on fluoride chemical shift for $\mathrm{CsF}$ in apolar solvent likely due to the difficulties of solubilizing the salt; strongly deshielded $\mathrm{F}^{-}$, however, has been observed in solid-state NMR of CsF. ${ }^{29}$

The crystallization of bisurea $\mathbf{1 3}$ in the presence of $\mathrm{CsF}$ gave a single crystal suitable for X-ray diffraction studies. ${ }^{30}$ In the solid state, 13:CsF formed columnar superstructures, where $\mathrm{Cs}^{+}$was bridged between $\mathrm{F}^{-}$and the two carbonyls of a second bisurea molecule, with each pair of bisurea being oriented in a head-to-tail arrangement (Figure 15). The complex showed 1:1 binding to fluoride, which was itself hydrogen-bonded to all three NH groups. The structure of the BINAM scaffold is highly similar to that of 2:TBAF; however, in 13: $\mathrm{CsF} \mathrm{NH}(\mathrm{c}) \cdots$ $\mathrm{F}^{-}$showed the longest hydrogen-bonding distance (Table 4). 


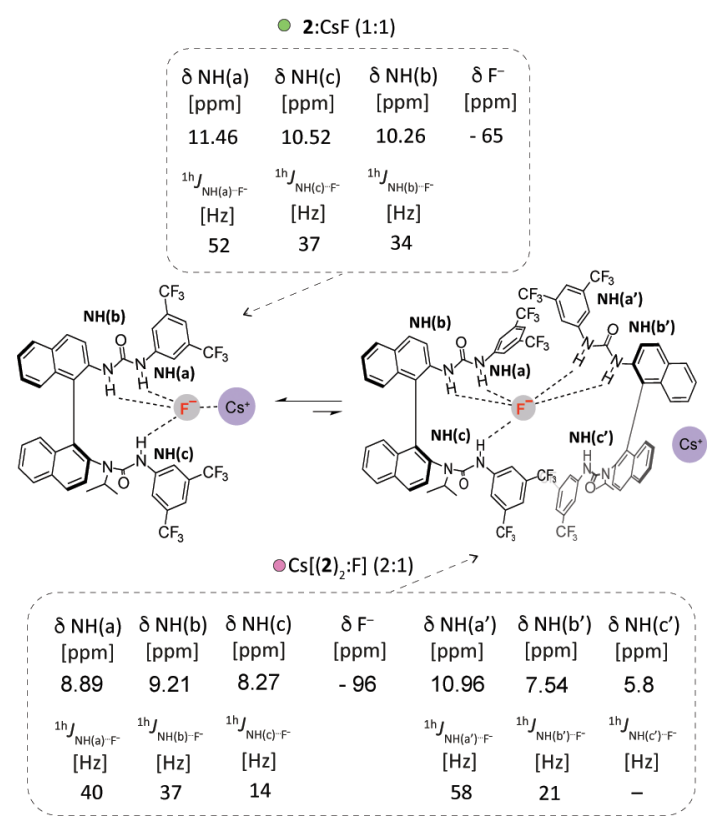

Figure 14. NMR parameters measured for $\mathrm{NH}$ resonances and $\mathrm{F}^{-}$of 2: $\mathrm{CsF}$ and $\mathrm{Cs}\left[(2)_{2}: \mathrm{F}\right]$.

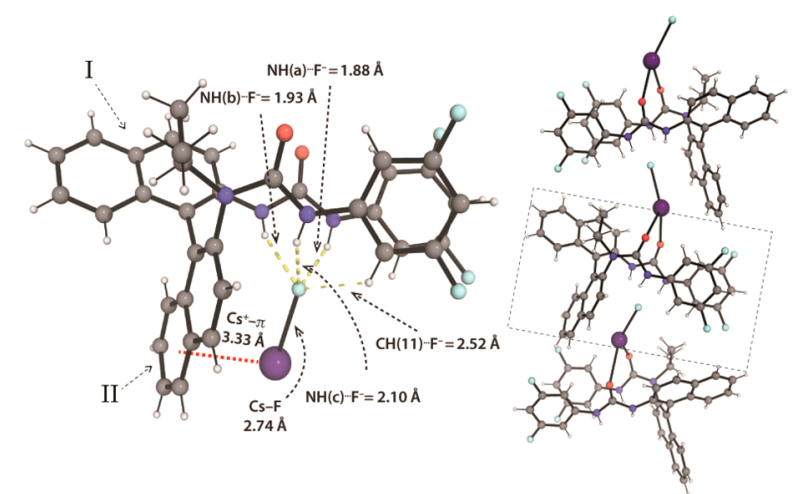

Figure 15. Solid-state structure of 13:CsF from single-crystal X-ray diffraction (solvent omitted for clarity).

Table 4. Relevant Internuclear Distances of 13: $\mathrm{F}^{-a}$

\begin{tabular}{|c|c|c|c|c|}
\hline \multirow[b]{2}{*}{$\mathrm{DH} \cdots \mathrm{A}$} & \multicolumn{3}{|c|}{$\mathrm{X}$-ray $13: \mathrm{CsF}$} & NMR 13:TBAF \\
\hline & $d \mathrm{D}-\mathrm{H}(\AA)$ & $d \mathrm{D} \cdots \mathrm{A}(\AA)$ & $d \mathrm{H} \cdots \mathrm{A}(\AA)$ & $d \mathrm{H} \cdots \mathrm{A}^{b}(\AA)$ \\
\hline $\mathrm{NH}(\mathrm{a}) \cdots \mathrm{F}^{-}$ & 0.85 & $2.641(7)$ & 1.88 & 1.83 \\
\hline $\mathrm{NH}(\mathrm{b}) \cdots \mathrm{F}^{-}$ & 0.87 & $2.727(6)$ & 1.93 & 2.05 \\
\hline $\mathrm{NH}(\mathrm{c}) \cdots \mathrm{F}^{-}$ & 0.85 & $2.837(6)$ & 2.10 & 1.91 \\
\hline $\mathrm{CH}(11) \cdots \mathrm{F}^{-}$ & 0.93 & $3.119(7)$ & 2.52 & \\
\hline
\end{tabular}

${ }^{a} \mathrm{D}=\mathrm{HB}$ donor, $\mathrm{A}=\mathrm{HB}$ acceptor. ${ }^{b}$ Determined by NMR from HOESY experiments on 13:TBAF.

A distinctive cation $-\pi$ interaction between $\mathrm{Cs}^{+}$and naphthyl(II) (distance of 3.3283(4) ^) was also prominent. Compared with the $\mathrm{NH} \cdots \mathrm{F}^{-}$distances of 13:TBAF determined by NMR in DCM-d $d_{2}$ (Table 4), an elongation of $\mathrm{NH}(\mathrm{c}) \cdots \mathrm{F}^{-}$and shortening of $\mathrm{NH}(\mathrm{b}) \cdots \mathrm{F}^{-}$were observed. $\mathrm{NH}(\mathrm{a}) \cdots \mathrm{F}^{-}$ displayed a similar $\mathrm{HB}$ distance in solution and in the solid state. The Cs $\cdots$ F distance for 13:CsF was 2.742(3) $\AA^{31}$ and $\mathrm{Cs}^{+}$displayed short-distance contacts with the two carbonyls of a neighboring bisurea, a multimeric arrangement likely reinforced by solid-state packing. In solution, the shielding for ${ }^{133} \mathrm{Cs}$ resonance was consistent with an interaction with fluoride as well as a cation $-\pi$ interaction with naphthyl. From these insights, it appears that $\mathrm{Cs}^{+}$in place of $\mathrm{TBA}^{+}$does not drastically affect the structure of the 1:1 catalyst-fluoride complex, apart from weakening $\mathrm{NH}(\mathrm{a}) \cdots \mathrm{F}^{-}$and $\mathrm{NH}(\mathrm{c}) \cdots \mathrm{F}^{-}$ interactions. The $\pi$-cation interaction of $\mathrm{Cs}^{+}$with BINAM directly contributes to the positioning of $\mathrm{Cs}^{+}$and indirectly to that of fluoride and its $\mathrm{HB}$ interactions. An analogous cation $-\pi$ contact between the positively charged episulfonium ion and naphthyl was found to be a key noncovalent interaction in the transition state (TS) leading to product formation. ${ }^{8 a}$

The observation that $\mathrm{Cs}^{+}$interacts with fluoride in the solid state and in solution has implications for catalytic fluorination under HB-PTC because the process requires ion metathesis between $\mathrm{Cs}^{+}$and the electrophile $\left(\mathrm{E}^{+}\right)$. Also, under catalytic conditions, the formation of $\mathrm{Cs}\left[(2)_{2}: \mathrm{F}\right]$ will depend on the rate of formation (phase transfer) and consumption (fluoride delivery) of 2:CsF. For fast fluorination involving highly reactive electrophiles, the formation of $\mathrm{Cs}\left[(2)_{2}: \mathrm{F}\right]$ will be kinetically unfavorable. However, under conditions favoring aggregation such as high concentration, low temperature, or poorly reactive electrophiles, one would assume that Cs$\left[(2)_{2}: \mathrm{F}\right]$ is present in solution.

Further information was gained on reactivity. To a solution of $2: \mathrm{CsF} / \mathrm{Cs}\left[(2)_{2}: \mathrm{F}\right]$ generated in situ by sonication of 2 and $\mathrm{CsF}$ in DCM- $d_{2}, \beta$-bromosulfide 1a ( 2 equiv) was added as a solid, and the sample was briefly agitated. This resulted in the instantaneous formation of a precipitate assigned as $\mathrm{CsBr} .{ }^{1} \mathrm{H}$ and ${ }^{19} \mathrm{~F}$ NMR analyses showed the presence of $\beta$-fluorosulfide 3 a formed with an enantiomeric ratio (e.r.) of 86.5:13.5, which is consistent with the enantioselectivity measured for the catalytic reaction (cf. e.r. $=88: 12$ ). This experiment unambiguously demonstrated that 2:CsF (in equilibrium with $\left.\mathrm{Cs}\left[(2)_{2}: \mathrm{F}\right]\right)$ is effective for the enantioselective fluorination of 1a, an observation that supports our mechanistic hypothesis (Figure 1A).

Impact of Multiple $\mathrm{H}$ Bonds to Fluoride on Catalytic Fluorination. Preliminary computational studies suggested that $2: \mathrm{F}^{-}$participates in the enantiodetermining step for the fluorination of meso-episulfonium ions under HB-PTC; ${ }^{8 a}$ striking structural similarities were found for the bisureafluoride anionic component featured in the TS and complex 2:TBAF in its ground state (in the solid state and in DCM- $d_{2}$ ). The structure and conformation of bisurea-fluoride complexes in their ground state could therefore provide valuable information to understand catalyst performance. Catalysts 113 were tested with the fluorination of $\beta$-bromosulfide 1a with CsF in DCM or 1,2-difluorobenzene (1,2-DFB) at room temperature for $1.5 \mathrm{~h}$ (Table 5). Initially, yields and enantioselectivities were determined for catalysts 3-7 bearing different $\mathrm{N}$-alkyl groups and compared with the results obtained with the nonalkylated bisurea 1 and $N$-iPr bisurea 2 (Table 5, entries 1-7). All catalysts 1-7 provided excellent yields (>95\%), implying that the 3,5-bis(trifluoromethyl)phenyl substituents ensure strong binding with fluoride and thus effective solid-liquid phase transfer for CsF. The nonalkylated BINAM urea 1 led to a lower e.r. compared to all $\mathrm{N}$-alkylated analogues (entry $2,86: 14$ e.r.) $\left(\Delta \Delta G^{\neq}=1.07\right.$ $\mathrm{kcal} / \mathrm{mol}$ ). For catalysts $4-6$, the level of enantioselectivity achieved is highly similar to that for 2 (e.r. 89.5:10.5-90:10); only the $\mathrm{N}$-methylated catalyst 3 provided $(S, S)$-3a in slightly lower e.r. (entry 3, e.r. 88:12). N-(3-Pentyl) catalyst 7 on the other hand led to slight improvement (entry 7, 91:9 e.r.) $\left(\Delta \Delta G^{\ddagger}=1.4 \mathrm{kcal} / \mathrm{mol}\right)$. 
Table 5. Evaluation of Catalytic Performance of Bisurea Catalysts ${ }^{a}$

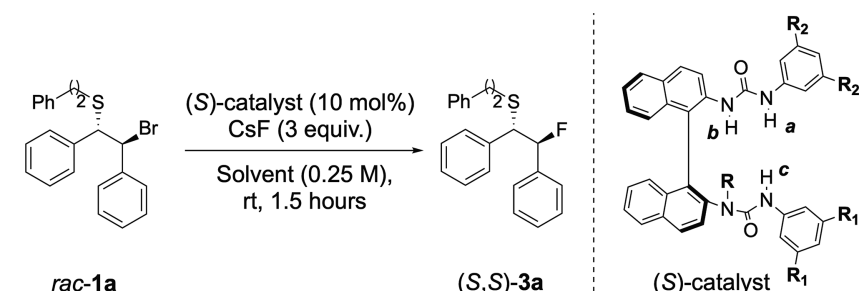

\begin{tabular}{|c|c|c|c|c|c|c|c|c|c|}
\hline \multirow[b]{2}{*}{ entry } & \multirow[b]{2}{*}{ catalyst } & \multirow[b]{2}{*}{$\mathrm{R}$} & \multirow[b]{2}{*}{$\mathrm{R}_{1}$} & \multirow[b]{2}{*}{$\mathrm{R}_{2}$} & \multirow[b]{2}{*}{${ }^{\mathrm{lh}} J_{\mathrm{NH}(\mathrm{a}, \mathrm{c}, \mathrm{b}) \cdots \mathrm{F}^{-}}(\mathrm{Hz})$} & \multicolumn{2}{|c|}{ 1,2-DFB } & \multicolumn{2}{|c|}{ DCM } \\
\hline & & & & & & yield $^{b}(\%)$ & e.r. ${ }^{c}$ & yield $^{b}(\%)$ & e.r. ${ }^{c}$ \\
\hline 1 & 2 & $i \operatorname{Pr}$ & & & $60,50,33$ & $>95$ & $90: 10$ & $>95$ & $88: 12$ \\
\hline 2 & 1 & $\mathrm{H}$ & & & 65 & $>95$ & $86: 14$ & $>95$ & $82: 18$ \\
\hline 3 & 3 & $\mathrm{Me}$ & & & $60,54,34$ & $>95$ & $88: 12$ & $>95$ & $83.5: 16.5$ \\
\hline 4 & 4 & Et & & & $61,54,34$ & $>95$ & $90: 10$ & $>95$ & $87.5: 12.5$ \\
\hline 5 & 5 & $n \operatorname{Pr}$ & & & $60,53,33$ & $>95$ & $89.5: 10.5$ & $>95$ & $88: 12$ \\
\hline 6 & 6 & cPentyl & & & $59,48,34$ & $>95$ & $89: 11$ & $>95$ & $87.5: 12.5$ \\
\hline 7 & 7 & 3-Pentyl & & & $61,52,34$ & $>95$ & $91: 9$ & $>95$ & $89.5: 10.5$ \\
\hline 8 & 8 & $i \operatorname{Pr}$ & $\mathrm{H}$ & $\mathrm{CF}_{3}$ & $63,39,34$ & 18 & $76.5: 23.5$ & 36 & $77: 23$ \\
\hline 9 & 9 & $i \operatorname{Pr}$ & $\mathrm{CF}_{3}$ & $\mathrm{H}$ & $53,52,33$ & 75 & $86.5: 13.5$ & 85 & $84: 16$ \\
\hline 10 & 10 & $i \operatorname{Pr}$ & $\mathrm{CF}_{3}$ & $\mathrm{Me}$ & $52,53,34$ & 48 & $87.5: 12.5$ & 80 & $84.5: 15.5$ \\
\hline 11 & 11 & $i \operatorname{Pr}$ & $\mathrm{F}$ & $\mathrm{CF}_{3}$ & $60,44,33$ & 68 & $81: 19$ & 18 & $79: 21$ \\
\hline 12 & 12 & $i \operatorname{Pr}$ & $\mathrm{CF}_{3}$ & $\mathrm{~F}$ & $59,51,33$ & $>95$ & $88.5: 11.5$ & $>95$ & $86: 14$ \\
\hline 13 & 13 & $i \operatorname{Pr}$ & & & $59,46,34$ & $>95$ & $72: 28$ & $>95$ & $74: 26$ \\
\hline
\end{tabular}

${ }^{a}$ General conditions: ${ }^{8 a}$ substrate $(0.05 \mathrm{mmol})$, catalyst $(0.005 \mathrm{mmol})$, and $\mathrm{CsF}(0.15 \mathrm{mmol})$ in $200 \mu \mathrm{L}$ of solvent stirred at $1200 \mathrm{rpm}$ for the indicated time. ${ }^{b}$ Determined by ${ }^{19} \mathrm{~F}$ NMR using 4-fluoroanisole as the internal standard. ${ }^{c}$ e.r. was determined by high-performance liquid chromatography (HPLC) analysis using a chiral stationary phase; 1,2-DFB = 1,2-difluorobenzene.

The small variation in e.r. for catalysts bearing different $N$ alkyl groups suggests that this structural variation does not play a prominent role in differentiating between the TSs leading to one or the other enantiomer. This is corroborated by NMR conformational analyses, X-ray structures, and DFT calculations, which indicate that the $N$-alkyl substituent points away from the catalyst pocket that binds fluoride. These data also inform that the tridentate fluoride binding mode of $\mathrm{N}$-alkylated catalysts $2-7$ is beneficial over bidentate binding to ensure higher e.r. as demonstrated with the lower performance of $\mathbf{1}$, which lacks an $N$-alkyl group. Next, $N$-isopropyl bisureas 8-13 served the purpose of investigating the influence of $\mathrm{NH}$-aryl substitution on both yields and e.r. (Table 5, entries 8-13). In this series, only catalysts 12 and 13 featuring fluorine substitution on both aryl rings afforded $3 a$ in $>95 \%$ yield, offering optimal performance as a phase-transfer catalyst for $\mathrm{CsF}$ and the ability to release fluoride for $\mathrm{C}-\mathrm{F}$ bond construction. The replacement of 3,5-bis(trifluoromethyl)phenyl for phenyl or meta-xylyl, as shown with catalysts 810, was detrimental as yields plummeted as low as $18 \%$, indicating poor phase-transfer capability. The most drastic effect was encountered when the aryl group attached to $\mathrm{NH}(\mathrm{c})$ lacked electron-deficient substituents (catalyst 8). Reactivity is dependent on the solvent, with catalysts 8-10 affording higher yields in DCM and catalyst 11 being much more effective in 1,2-DFB. The trends in enantioselectivity are similar in both solvents, with 1,2-DFB giving more often higher enantiomeric ratios. In this series, catalyst $\mathbf{1 3}$ is the least effective in terms of enantiocontrol. In all cases, no side products were detected in the crude mixture based on ${ }^{1} \mathrm{H}$ NMR analysis.

The NMR data of the best-performing catalyst-TBAF complexes indicate that bisureas having stronger $\mathrm{NH}(\mathrm{c}) \cdots \mathrm{F}^{-}$ contribution (larger ${ }^{1 \mathrm{~h}} \mathrm{~J}_{\mathrm{NH}(\mathrm{c}) \cdots \mathrm{F}^{-}}$) typically lead to a superior reaction outcome, suggesting that $\mathrm{NH}(\mathrm{c}) \cdots \mathrm{F}^{-}$is a key interaction for achieving high yield and enantioselectivity. The striking role of $\mathrm{NH}(\mathrm{c})$ was highlighted in our original report, which presented intrinsic reaction coordinates to shed light on the mechanism of the reaction. ${ }^{8 a}$ The calculations showed that the three $\mathrm{NH} \cdots \mathrm{F}^{-}$hydrogen bonds elongated during fluoride delivery to the episulfonium ion as a consequence of charge neutralization; however, the elongation of $\mathrm{NH}(\mathrm{c}) \cdots \mathrm{F}^{-}$occurred faster compared to those of $\mathrm{NH}(\mathrm{a}) \cdots$ $\mathrm{F}^{-}$and $\mathrm{NH}(\mathrm{b}) \cdots \mathrm{F}^{-}$.

\section{CONCLUSION}

This investigation has unveiled important information on the conformation of BINAM-derived bisureas and their ability to bind fluoride in solution. Analysis of a set of bisureas featuring up to four $\mathrm{NH}$ groups enabled us to draw conclusions on the effect of multiple hydrogen bonds to fluoride on catalytic nucleophilic fluorination. The key findings are summarized hereafter.

- In DCM- $d_{2}(25 \mathrm{mM}), \mathrm{N}$-alkylated BINAM-derived bisureas with three $\mathrm{NH}$ groups exist as equilibrating structures resulting from an intramolecular time-dependent hydrogen bond that involves the two urea motifs. The corresponding nonalkylated BINAM bisurea with four $\mathrm{HB}$ donor NHs does not display such intramolecular interaction but undergoes aggregation when the concentration increases.

- Nonalkylated and alkylated bisureas bind fluoride in DCM- $d_{2}$, resulting in the formation of two equilibrating species: a 2:1 bisurea- $\mathrm{F}^{-}$complex at low TBAF stoichiometry and a more stable 1:1 complex dominant when TBAF stoichiometry is $>1$ equiv. Conformational analysis by quantitative NOESY informed that $\mathrm{N}$-alkylated bisureas underwent anti-anti to syn-anti isomerization of the $\mathrm{N}$ alkylated urea upon addition of TBAF. This conformational change led to a dynamically stable 1:1 complex, allowing all 
three NHs to bind fluoride, an arrangement similar to the conformation observed for this complex in the solid state. The corresponding nonalkylated bisurea binds fluoride, engaging two of its four $\mathrm{NH}$ groups.

- Hydrogen-bond coupling constants $\left({ }^{1 \mathrm{~h}} J_{\mathrm{NH} \cdots \mathrm{F}^{-}}\right)$were observed and measured by ${ }^{1} \mathrm{H}-{ }^{19} \mathrm{~F}$ CLIP-HSQC experiments, providing insight into the hydrogen-bonding network around fluoride, with distances calculated from ${ }^{1} \mathrm{H}-{ }^{19} \mathrm{~F}$ NOE experiments. All $\mathrm{N}$-alkylated bisurea catalysts bind fluoride, with all three NHs participating in hydrogen bonding. $\mathrm{NH}(\mathrm{a})$, located on the nonalkylated urea submotif and away from naphthyl, was the dominant contributor to the $\mathrm{HB}$ network $\left({ }^{1 \mathrm{~h}} \mathrm{~J}_{\mathrm{NH}(\mathrm{a}) \cdots \mathrm{F}^{-}}\right.$ $\approx 60 \mathrm{~Hz}$ ), while $\mathrm{NH}(\mathrm{c})$, belonging to the $\mathrm{N}$-alkylated urea, varied significantly as a function of its electronic environment $\left({ }^{1 \mathrm{~h}} \mathrm{~J}_{\mathrm{NH}(\mathrm{c}) \cdots \mathrm{F}^{-}} \approx 40-50 \mathrm{~Hz}\right)$. Hydrogen bonding with $\mathrm{NH}(\mathrm{b})$ located inside the cavity of the catalyst was the weakest interaction $\left({ }^{\mathrm{lh}} \mathrm{J}_{\mathrm{NH}(\mathrm{b}) \cdots \mathrm{F}^{-}} \approx 33-34 \mathrm{~Hz}\right)$. In contrast, only two of the four $\mathrm{NH}$ groups of nonalkylated BINAM bisurea 1 displayed $\mathrm{HB}$ with fluoride $\left({ }^{1 \mathrm{~h}} \mathrm{~J}_{\mathrm{NH}(\mathrm{a}) \cdots \mathrm{F}^{-}}=65 \mathrm{~Hz}\right)$; the $\mathrm{NHs}$ involved are those proximal to the 3,5-bis(trifluoromethyl)phenyl rings.

- A bisurea-fluoride complex prepared from CsF was characterized in solution and in the solid state. Lowtemperature $\mathrm{NMR}$ and ${ }^{1} \mathrm{H}$ diffusion experiments revealed two species in equilibrium, a 1:1 bisurea-CsF complex as the main species along with a less-abundant 2:1 complex (85:15 at $298 \mathrm{~K}) .{ }^{\mathrm{lh}} \mathrm{J}_{\mathrm{NH} \cdots \mathrm{F}^{-}}$detection provided information on the binding mode, with the 1:1 species showing a four-centered trifurcated $\mathrm{HB}$ with fluoride $\left({ }^{1 \mathrm{~h}} \mathrm{~J}_{\mathrm{NH}(\mathrm{a}) \cdots \mathrm{F}^{-}}=52 \mathrm{~Hz},{ }^{1 \mathrm{~h}} \mathrm{~J}_{\mathrm{NH}(\mathrm{c}) \cdots \mathrm{F}^{-}}=\right.$ $37 \mathrm{~Hz}$, and ${ }^{1 \mathrm{~h}} \mathrm{~J}_{\mathrm{NH}(\mathrm{b}) \cdots \mathrm{F}^{-}}=34 \mathrm{~Hz}$ ). The $2: 1$ bisurea-CsF led to a six-centered hydrogen-bond network, engaging both bisureas as hydrogen-bond donors $\left({ }^{1 \mathrm{~h}} J_{\mathrm{NH}(\mathrm{a}) \cdots \mathrm{F}^{-}}=40 \mathrm{~Hz},{ }^{1 \mathrm{~h}} J_{\mathrm{NH}(\mathrm{b}) \cdots \mathrm{F}^{-}}=\right.$ $37 \mathrm{~Hz},{ }^{1 h} J_{\mathrm{NH}(\mathrm{c}) \cdots \mathrm{F}^{-}}=14 \mathrm{~Hz},{ }^{1 \mathrm{~h}} \mathrm{~J}_{\mathrm{NH}\left(\mathrm{a}^{\prime}\right) \cdots \mathrm{F}^{-}}=58 \mathrm{~Hz}$, and $\left.{ }^{1 h} J_{\mathrm{NH}\left(\mathrm{b}^{\prime}\right) \cdots \mathrm{F}^{-}}=21 \mathrm{~Hz}\right)$. Spectroscopic studies of the 1:1 complex agreed with the solid-state structure from single-crystal X-ray diffraction, indicating that the $\mathrm{Cs}^{+}$ion interacted both with naphthyl via a cation $-\pi$ interaction and with $\mathrm{F}^{-}$. These interactions resulted in some reorganization of the HB network in the catalytic pocket, with $\mathrm{NH}(\mathrm{a}) \cdots \mathrm{F}^{-}$and $\mathrm{NH}(\mathrm{c}) \cdots \mathrm{F}^{-}$ interactions reduced compared to those observed in the corresponding TBAF complex. The reaction of the preformed bisurea-CsF complex with a model $\beta$-bromosulfide led to instantaneous formation of the expected enantioenriched $\beta$ fluorosulfide; this experiment demonstrated that this bisureaCsF complex enabled asymmetric fluorination with fast fluoride delivery.

- Catalytic fluorinations carried out with thirteen bisurea catalysts all characterized by NMR spectroscopy provided additional insight. Excellent reactivity was observed for all catalysts with electron-withdrawing substituents on the $\mathrm{N}$-aryl groups, suggesting that this electronic pattern was necessary for the catalyst to act as a phase-transfer agent for CsF. The resulting bisurea-fluoride complexes remained competent nucleophiles and provided the necessary chiral environment for enantioselective fluoride delivery. The data show that the hydrogen-bond interaction $\mathrm{NH}(\mathrm{c}) \cdots \mathrm{F}^{-}$was critical to ensure good control over enantioselectivity. The nonalkylated bisurea gave the desired product in high yield, indicating that the formation of a three-centered bifurcated fluoride complex was sufficient for phase-transfer but not optimal for enantioselectivity.

In this study, we demonstrated that ${ }^{1} \mathrm{H} /{ }^{19} \mathrm{~F}$ NMR spectroscopy is a powerful tool to analyze multiple $\mathrm{H}$-bonding interactions with fluoride, thereby offering insight into catalyst performance for enantioselective nucleophilic fluorination under HB-PTC. Considering the importance of hydrogenbonding interactions in catalysis, we anticipate that the analytical approach described herein would encourage further investigations with a multitude of catalyst candidates featuring multiple hydrogen-bond donor functionalities that are capable of anion binding.

\section{ASSOCIATED CONTENT}

\section{SI Supporting Information}

The Supporting Information is available free of charge at https://pubs.acs.org/doi/10.1021/jacs.0c09832.

NMR methods and characterization, binding studies, hydrogen-bond coupling, catalyst synthesis and characterization, and NMR spectra (PDF) Crystallographic data of 13: CsF (CIF)

\section{AUTHOR INFORMATION}

\section{Corresponding Authors}

Timothy D. W. Claridge - Chemistry Research Laboratory, University of Oxford, Oxford OX1 3TA, United Kingdom; 다이.org/0000-0001-5583-6460; Email: tim.claridge@ chem.ox.ac.uk

Véronique Gouverneur - Chemistry Research Laboratory, University of Oxford, Oxford OX1 3TA, United Kingdom; () orcid.org/0000-0001-8638-5308;

Email: veronique.gouverneur@chem.ox.ac.uk

\section{Authors}

Francesco Ibba - Chemistry Research Laboratory, University of Oxford, Oxford OX1 3TA, United Kingdom; (1) orcid.org/0000-0002-2739-4156

Gabriele Pupo - Chemistry Research Laboratory, University of Oxford, Oxford OX1 3TA, United Kingdom; (1) orcid.org/0000-0003-3084-3888

Amber L. Thompson - Chemistry Research Laboratory, University of Oxford, Oxford OX1 3TA, United Kingdom

John M. Brown - Chemistry Research Laboratory, University of Oxford, Oxford OX1 3TA, United Kingdom

Complete contact information is available at:

https://pubs.acs.org/10.1021/jacs.0c09832

\section{Funding}

This work was supported by the European Union's Horizon 2020 research and innovation program under the Marie Skłodowska-Curie Grant agreement nos. 675071 and 789553, the EPSRC (EP/R010064), and the ERC (Grant agreement no. 832994).

\section{Notes}

The authors declare no competing financial interest. Crystallographic data have been deposited with the Cambridge Crystallographic Data Centre (2031585) and can be obtained free of charge via http://www.ccdc.cam.ac.uk/data_request/ cif.

\section{ACKNOWLEDGMENTS}

We thank Dr. Nader Amin for insightful discussions. We thank Prof. Matthew J. Langton and Aidan Kerckhoffs for their help with UV-vis spectroscopy and Dr. Petr Kuzmic for helpful discussions about Dynafit. 


\section{REFERENCES}

(1) (a) Doyle, A. G.; Jacobsen, E. N. Small-Molecule H-Bond Donors in Asymmetric Catalysis. Chem. Rev. 2007, 107, 5713-5743. (b) Taylor, M. S.; Jacobsen, E. N. Asymmetric Catalysis by Chiral Hydrogen-Bond Donors. Angew. Chem. Int. Ed. 2006, 45, 1520-1543.

(2) Pihko, P. Introduction. In Hydrogen Bonding in Organic Synthesis; John Wiley \& Sons, Ltd.: 2009.

(3) Brak, K.; Jacobsen, E. N. Asymmetric Ion-Pairing Catalysis. Angew. Chem. Int. Ed. 2013, 52, 534-561.

(4) (a) Kotke, M.; Schreiner, P. R. Acid-Free, Organocatalytic Acetalization. Tetrahedron 2006, 62, 434-439. (b) Kotke, M.; Schreiner, P. R. Generally Applicable Organocatalytic Tetrahydropyranylation of Hydroxy Functionalities with Very Low Catalyst Loading. Synthesis 2007, 2007, 779-790. (c) Weil, T.; Kotke, M.; Kleiner, C. M.; Schreiner, P. R. Cooperative Brønsted Acid-Type Organocatalysis: Alcoholysis of Sytrene Oxides. Org. Lett. 2008, 10, 15131516.

(5) (a) Taylor, M. S.; Jacobsen, E. N. Highly Enantioselective Catalytic Acyl-Pictet-Spengler Reactions. J. Am. Chem. Soc. 2004, 126, 10558-10559. (b) Taylor, M. S.; Tokunaga, N.; Jacobsen, E. N. Enantioselective Thiourea-Catalyzed Acyl-Mannich Reactions of Isoquinolines. Angew. Chem. Int. Ed. 2005, 44, 6700-6704. (c) Reisman, S. E.; Doyle, A. G.; Jacobsen, E. N. Enantioselective ThioureaCatalyzed Additions to Oxocarbenium Ions. J. Am. Chem. Soc. 2008 130, 7198-7199.

(6) (a) Banik, S. M.; Levina, A.; Hyde, A. M.; Jacobsen, E. N. Lewis Acid Enhancement by Hydrogen-Bond Donors for Asymmetric Catalysis. Science 2017, 358, 761-764. (b) Wendlandt, A. E.; Vangal, P.; Jacobsen, E. N. Quaternary Stereocentres via an Enantioconvergent Catalytic $S_{N} 1$ Reaction. Nature 2018, 556, 447451. (c) Metternich, J.; Reiterer, M.; Jacobsen, E. Asymmetric Nazarov Cyclizations of Unactivated Dienones by Hydrogen-BondDonor/Lewis Acid Co-Catalyzed, Enantioselective Proton-Transfer. Adv. Synth. Catal. 2020, 362, 4092-4097.

(7) (a) Strassfeld, D. A.; Wickens, Z. K.; Picazo, E.; Jacobsen, E. N. Highly Enantioselective, Hydrogen-Bond-Donor Catalyzed Additions to Oxetanes. J. Am. Chem. Soc. 2020, 142, 9175-9180. (b) Birrell, J. A.; Desrosiers, J.-N.; Jacobsen, E. N. Enantioselective Acylation of Silyl Ketene Acetals through Fluoride Anion-Binding Catalysis. J. Am. Chem. Soc. 2011, 133, 13872-13875. (c) De, C. K.; Mittal, N.; Seidel, D. A Dual-Catalysis Approach to the Asymmetric Steglich Rearrangement and Catalytic Enantioselective Addition of O-Acylated Azlactones to Isoquinolines. J. Am. Chem. Soc. 2011, 133, 1680216805. (d) Jarvis, C. L.; Hirschi, J. S.; Vetticatt, M. J.; Seidel, D. Catalytic Enantioselective Synthesis of Lactams through Formal [4+ 2] Cycloaddition of Imines with Homophthalic Anhydride. Angew. Chem. Int. Ed. 2017, 56, 2670-2674.

(8) (a) Pupo, G.; Ibba, F.; Ascough, D. M. H.; Vicini, A. C.; Ricci, P.; Christensen, K. E.; Pfeifer, L.; Morphy, J. R.; Brown, J. M.; Paton, R. S.; Gouverneur, V. Asymmetric Nucleophilic Fluorination under Hydrogen Bonding Phase-Transfer Catalysis. Science 2018, 360, 638642. (b) Pupo, G.; Vicini, A. C.; Ascough, D. M. H.; Ibba, F.; Christensen, K. E.; Thompson, A. L.; Brown, J. M.; Paton, R. S.; Gouverneur, V. Hydrogen Bonding Phase-Transfer Catalysis with Potassium Fluoride: Enantioselective Synthesis of $\beta$-Fluoroamines. J. Am. Chem. Soc. 2019, 141, 2878-2883. (c) Roagna, G.; Ascough, D. M. H.; Ibba, F.; Vicini, A. C.; Fontana, A.; Christensen, K. E.; Peschiulli, A.; Oehlrich, D.; Misale, A.; Trabanco, A. A.; Paton, R. S.; Pupo, G.; Gouverneur, V. Hydrogen Bonding Phase-Transfer Catalysis with Ionic Reactants: Enantioselective Synthesis of $\gamma$ Fluoroamines. J. Am. Chem. Soc. 2020, 142, 14045-14051.

(9) O’Hagan, D.; Schaffrath, C.; Cobb, S. L.; Hamilton, J. T. G.; Murphy, C. D. Biosynthesis of an Organofluorine Molecule. Nature 2002, 416, 279-279.

(10) (a) Busschaert, N.; Caltagirone, C.; Van Rossom, W.; Gale, P. A. Applications of Supramolecular Anion Recognition. Chem. Rev. 2015, 115, 8038-8155. (b) Evans, N. H.; Beer, P. D. Advances in Anion Supramolecular Chemistry: From Recognition to Chemical Applications. Angew. Chem. Int. Ed. 2014, 53, 11716-11754. (c) Cametti, M.; Rissanen, K. Recognition and Sensing of Fluoride Anion. Chem. Commun. 2009, No. 20, 2809. (d) Woods, C. J.; Camiolo, S.; Light, M. E.; Coles, S. J.; Hursthouse, M. B.; King, M. A.; Gale, P. A.; Essex, J. W. Fluoride-Selective Binding in a New Deep Cavity Calix[4]Pyrrole: Experiment and Theory. J. Am. Chem. Soc. 2002, 124, 8644-8652. (e) Clarke, H. J.; Howe, E. N. W.; Wu, X.; Sommer, F.; Yano, M.; Light, M. E.; Kubik, S.; Gale, P. A. Transmembrane Fluoride Transport: Direct Measurement and Selectivity Studies. J. Am. Chem. Soc. 2016, 138, 16515-16522.

(11) (a) Liang, S.; Hammond, G. B.; Xu, B. Hydrogen Bonding: Regulator for Nucleophilic Fluorination. Chem. - Eur. J. 2017, 23, 17850-17861. (b) Lee, J.-W.; Oliveira, M. T.; Jang, H. B.; Lee, S.; Chi, D. Y.; Kim, D. W.; Song, C. E. Hydrogen-Bond Promoted Nucleophilic Fluorination: Concept, Mechanism and Applications in Positron Emission Tomography. Chem. Soc. Rev. 2016, 45, 46384650. (c) Engle, K. M.; Pfeifer, L.; Pidgeon, G. W.; Giuffredi, G. T.; Thompson, A. L.; Paton, R. S.; Brown, J. M.; Gouverneur, V. Coordination Diversity in Hydrogen-Bonded Homoleptic FluorideAlcohol Complexes Modulates Reactivity. Chem. Sci. 2015, 6, 52935302. (d) Pfeifer, L.; Engle, K. M.; Pidgeon, G. W.; Sparkes, H. A.; Thompson, A. L.; Brown, J. M.; Gouverneur, V. Hydrogen-Bonded Homoleptic Fluoride-Diarylurea Complexes: Structure, Reactivity, and Coordinating Power. J. Am. Chem. Soc. 2016, 138, 13314-13325. (e) Tonouchi, Y.; Matsumoto, K.; Nagata, T.; Katahira, M.; Hagiwara, R. Fluoride Ion Interactions in Alkali-Metal Fluoride-Diol Complexes. Inorg. Chem. 2020, 59, 6631-6639.

(12) ${ }^{n h} J_{X Y}$ notation indicates $J$-coupling between nuclei $\mathrm{X}$ and $\mathrm{Y}$ across $n$ bonds, where the superscript $h$ indicates the participation of one hydrogen bond to the coupling mechanism.

(13) For details, see the Supporting Information.

(14) Semetey, V.; Hemmerlin, C.; Didierjean, C.; Schaffner, A. P.; Giner, A. G.; Aubry, A.; Briand, J. P.; Marraud, M.; Guichard, G. Unexpected Stability of the Urea Cis-Trans Isomer in UreaContaining Model Pseudopeptides. Org. Lett. 2001, 3, 3843-3845.

(15) Kleckner, I. R.; Foster, M. P. An Introduction to NMR-Based Approaches for Measuring Protein Dynamics. Biochim. Biophys. Acta, Proteins Proteomics 2011, 1814, 942-968.

(16) The software DynaFit 4 is available to download at http:// www.biokin.com and can be used for research purposes under free academic license. Kuzmič, P. Program DYNAFIT for the Analysis of Enzyme Kinetic Data: Application to HIV Proteinase. Anal. Biochem. 1996, 237, 260-273.

(17) The presence of a 2:1 $\left[\mathrm{U}_{2} \mathrm{~F}\right]^{-}$intermediate is evident from the titration profile of catalyst 1 , which has a minimum for $\left[\mathrm{F}^{-}\right]=0.5$ equiv; for catalyst 2, this is inferred by data modeling. Refer to Figure S35 for a comparison between 1:1 and 1:1 plus 2:1 binding mode, with the latter scenario resulting in a superior fitting.

(18) (a) Dingley, A. J.; Cordier, F.; Grzesiek, S. An Introduction to Hydrogen Bond Scalar Couplings. Concepts Magn. Reson. 2001, 13, 103-127. (b) Scheurer, C.; Brüschweiler, R. Quantum-Chemical Characterization of Nuclear Spin-Spin Couplings across Hydrogen Bonds. J. Am. Chem. Soc. 1999, 121, 8661-8662. (c) Benedict, H.; Shenderovich, I. G.; Malkina, O. L.; Malkin, V. G.; Denisov, G. S.; Golubev, N. S.; Limbach, H. H. Nuclear Scalar Spin-Spin Couplings and Geometries of Hydrogen Bonds. J. Am. Chem. Soc. 2000, 122, 1979-1988.

(19) (a) Dingley, A. J.; Grzesiek, S. Direct Observation of Hydrogen Bonds in Nucleic Acid Base Pairs by Internucleotide ${ }^{2} J_{\mathrm{NN}}$ Couplings. J. Am. Chem. Soc. 1998, 120, 8293-8297. (b) Cornilescu, G.; Ramirez, B. E.; Frank, M. K.; Clore, G. M.; Gronenborn, A. M.; Bax, A. Correlation between ${ }^{3 \mathrm{~h}} \mathrm{~J}_{\mathrm{NC}}$ and Hydrogen Bond Length in Proteins. J. Am. Chem. Soc. 1999, 121, 6275-6279. (c) Tuttle, T.; Kraka, E.; Wu, A.; Cremer, D. Investigation of the NMR Spin-Spin Coupling Constants across the Hydrogen Bonds in Ubiquitin: The Nature of the Hydrogen Bond as Reflected by the Coupling Mechanism. J. Am. Chem. Soc. 2004, 126, 5093-5107.

(20) For an example of hydrogen-bond coupling $\left({ }^{2 \mathrm{~h}} \mathrm{~J}_{\mathrm{PH}},{ }^{3 \mathrm{~h}} \mathrm{~J}_{\mathrm{PN}}\right)$ in chiral phosphoric acid-imine complexes, see: Sorgenfrei, N.; Hioe, J.; Greindl, J.; Rothermel, K.; Morana, F.; Lokesh, N.; Gschwind, R. M. 
NMR Spectroscopic Characterization of Charge Assisted Strong Hydrogen Bonds in Brønsted Acid Catalysis. J. Am. Chem. Soc. 2016, 138, 16345-16354.

(21) Shenderovich, I. G.; Smirnov, S. N.; Denisov, G. S.; Gindin, V. A.; Golubev, N. S.; Dunger, A.; Reibke, R.; Kirpekar, S.; Malkina, O. L.; Limbach, H.-H. Nuclear Magnetic Resonance of Hydrogen Bonded Clusters between $\mathrm{F}^{-}$and $(\mathrm{HF})_{\mathrm{n}}$ : Experiment and Theory. Ber. Bunsen. Phys. Chem. 1998, 102, 422-428.

(22) (a) Kang, S. O.; Day, V. W.; Bowman-James, K. Fluoride: Solution- and Solid-State Structural Binding Probe. J. Org. Chem. 2010, 75, 277-283. (b) Kang, S. O.; VanderVelde, D.; Powell, D.; Bowman-James, K. Fluoride-Facilitated Deuterium Exchange from DMSO- $\mathrm{d}_{6}$ to Polyamide-Based Cryptands. J. Am. Chem. Soc. 2004, 126, 12272-12273. (c) Gale, P. A.; Sessler, J. L.; Kral, V. Calixpyrroles. Chem. Commun. 1998, 0, 1-8. (d) Chmielewski, M. J.; Jurczak, J. Anion Recognition by Neutral Macrocyclic Amides. Chem. Eur. J. 2005, 11, 6080-6094.

(23) Enthart, A.; Freudenberger, J. C.; Furrer, J.; Kessler, H.; Luy, B. The CLIP/CLAP-HSQC: Pure Absorptive Spectra for the Measurement of One-Bond Couplings. J. Magn. Reson. 2008, 192, 314-322.

(24) The chemical shift of TBAF- $3 \mathrm{H}_{2} \mathrm{O}$ in DCM- $d_{2}$ is similar to the one of $\mathrm{F}^{-}$in $\mathrm{H}_{2} \mathrm{O}$, denoting the presence of a prominent hydration sphere around fluoride.

(25) Measured from neutron diffraction structures of ref $11 \mathrm{~d}$.

(26) Macur, S.; Farmer, B. T.; Brown, L. R. An Improved Method for the Determination of Cross-Relaxation Rates from NOE Data. J. Magn. Reson. 1986, 70, 493-499.

(27) This is consistent with an increase in paramagnetic shielding of fluoride upon formation of a strong hydrogen-bonded complex $\left(n_{\mathrm{F}}^{-}\right.$ $\rightarrow \sigma^{*}{ }_{\mathrm{NH}}$ ). For details, see: (a) Gerken, M.; Boatz, J.; Kornath, A.; Haiges, R.; Schneider, S.; Schroer, T.; Christe, K. The NMR Shifts Are Not a Measure for the Nakedness of the Fluoride Anion. J. Fluor. Chem. 2002, 116, 49-58. (b) Dahanayake, J. N.; Kasireddy, C.; Karnes, J. P.; Verma, R.; Steinert, R. M.; Hildebrandt, D.; Hull, O. A.; Ellis, J. M.; Mitchell-Koch, K. R. Progress in Our Understanding of ${ }^{19}$ F Chemical Shifts. In Annual Reports on NMR Spectroscopy; Webb, G. A., Ed.; Academic Press: 2018; pp 281-365.

(28) Pollak, D.; Goddard, R.; Pörschke, K. R. Cs $\left[\mathrm{H}_{2} \mathrm{NB}_{2}\left(\mathrm{C}_{6} \mathrm{~F}_{5}\right)_{6}\right]$ Featuring an Unequivocal 16-Coordinate Cation. J. Am. Chem. Soc. 2016, 138, 9444-9451.

(29) Hayashi, S.; Hayamizu, K. Accurate Determination of NMR Chemical Shifts in Alkali Halides and Their Correlation with Structural Factors. Bull. Chem. Soc. Jpn. 1990, 63, 913-919.

(30) Single-crystal X-ray diffraction data were collected using a (Rigaku) Oxford Diffraction Supernova A diffractometer $(\lambda=1.54184$ $\AA$ ) and reduced using CrysAlisPro. The structure was solved using SuperFlip: Palatinus, L.; Chapuis, G. J. Appl. Crystallogr. 2007, 40, 786-790 and refined using CRYSTALS. (a) Betteridge, P. W.; Carruthers, J. R.; Cooper, R. I.; Prout, K.; Watkin, D. J. J. Appl. Crystallogr. 2003, 36, 1487. (b) Parois, P.; Cooper, R. I.; Thompson, A. L. Chem. Cent. J. 2015, 9, 30. (c) Cooper, R. I.; Thompson, A. L.; Watkin, D. J. J. Appl. Crystallogr. 2010, 43, 1100-1107. Full refinement details can be found in the Supporting Information; crystallographic data have also been deposited with the Cambridge Crystallographic Data Centre (CCDC 2031585).

(31) For Cs ‥F distances of CsF and CsF complexes, see: (a) Davey, W. P. Precision measurements of crystals of the alkali halides. Phys. Rev. 1923, 21, 143-161. (b) Sessler, J. L.; Kim, S. K.; Gross, D. E.; Lee, C.-H.; Kim, J. S.; Lynch, V. M. Crown-6-Calix[4]Arene-Capped Calix[4]Pyrrole: An Ion-Pair Receptor for Solvent-Separated CsF Ions. J. Am. Chem. Soc. 2008, 130, 13162-13166. (c) Yang, J. H.; Lynch, V. M.; Sessler, J. L.; Kim, S. K. Cesium Halide Ion Pair Recognition by a Pyrrole Strapped Calix [4] Pyrrole. Supramol. Chem. 2019, 31, 203-210. 